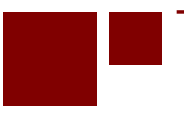

C E N T E R for RETIREMENT RESEARCH

at BOSTON COLLEGE

\title{
CALCULATING EXPECTED SOCIAL SECURITY BENEFITS BY RACE, EDUCATION, AND CLAIMING AGE
}

\author{
Geoffrey T. Sanzenbacher and Jorge D. Ramos-Mercado
}

CRR WP 2016-14

November 2016

\author{
Center for Retirement Research at Boston College \\ Hovey House \\ 140 Commonwealth Avenue \\ Chestnut Hill, MA 02467 \\ Tel: 617-552-1762 Fax: 617-552-0191 \\ http://crr.bc.edu
}

Geoffrey T. Sanzenbacher is a research economist at the Center for Retirement Research at Boston College (CRR). Jorge D. Ramos-Mercado is a research associate at the CRR. The research reported herein was performed pursuant to a grant from the U.S. Social Security Administration (SSA) funded as part of the Retirement Research Consortium. The opinions and conclusions expressed are solely those of the authors and do not represent the opinions or policy of SSA, any agency of the federal government, or Boston College. Neither the United States Government nor any agency thereof, nor any of their employees, makes any warranty, express or implied, or assumes any legal liability or responsibility for the accuracy, completeness, or usefulness of the contents of this report. Reference herein to any specific commercial product, process or service by trade name, trademark, manufacturer, or otherwise does not necessarily constitute or imply endorsement, recommendation or favoring by the United States Government or any agency thereof.

(C) 2016, Geoffrey T. Sanzenbacher and Jorge D. Ramos-Mercado. All rights reserved. Short sections of text, not to exceed two paragraphs, may be quoted without explicit permission provided that full credit, including (C) notice, is given to the source. 


\begin{abstract}
About the Center for Retirement Research
The Center for Retirement Research at Boston College, part of a consortium that includes parallel centers at the University of Michigan and the National Bureau of Economic Research, was established in 1998 through a grant from the Social Security Administration. The Center's mission is to produce first-class research and forge a strong link between the academic community and decision-makers in the public and private sectors around an issue of critical importance to the nation's future. To achieve this mission, the Center sponsors a wide variety of research projects, transmits new findings to a broad audience, trains new scholars, and broadens access to valuable data sources.
\end{abstract}

Center for Retirement Research at Boston College

Hovey House

140 Commonwealth Ave

Chestnut Hill, MA 02467

Tel: 617-552-1762 Fax: 617-552-0191

http://crr.bc.edu

Affiliated Institutions:

The Brookings Institution

Syracuse University

Urban Institute 


\begin{abstract}
The option to claim Social Security before the full retirement age (FRA) has been around for over 50 years. But claiming benefits early has an inherent trade-off: more years of income are received in exchange for an actuarially reduced monthly benefit. The actuarial reduction is designed to be "fair" for the average worker in that, regardless of the age at which a person claims, he can expect to receive the same expected present value (EPV) of his lifetime benefits. Aside from a period of high interest rates in the 1980s, this equality has roughly held for the average worker since the inception of the actuarial reduction. But the key word here is average. Workers who live less long than the average might maximize the EPV of benefits by claiming early, while those who live longer than average might benefit more from delay. This paper analyzes this issue by calculating the EPV of Social Security benefits by race, education, and gender, all three of which are correlates of both mortality and earnings.
\end{abstract}

This paper found that:

- Non-Hispanic men, both black and white, who do not hold a college degree maximize their EPV of benefits by claiming before the full retirement age, especially using a 3percent interest rate in the EPV calculation.

- On the other hand, white men with a college degree and white women with at least a high school degree maximize the EPV of their benefits when claiming after their FRAs.

- Within some groups, delayed claiming can result in a substantially higher EPV than early claiming, given today's low interest rates. For white female college graduates, the maximum EPV occurs at age 70 and is 16 percent higher than the EPV at 62, assuming an interest rate of 1 percent.

The policy implications of this paper are:

- More educated workers have more incentive to delay claiming than less educated workers, and non-blacks have more incentive to do so than blacks.

- Since the EPV is not a welfare measure, this result does not necessarily advocate early claiming for some, but it does point to differential incentives across socioeconomic groups. 
- Since some workers can maximize their EPV by claiming at 62 , policies that delay the early eligibility age to 64 but hold the actuarial reduction constant would cause some workers to sacrifice expected lifetime benefits, although the decrease is small. 


\section{Introduction}

The option to claim Social Security benefits before the Full Retirement Age (FRA) has been in place for over 50 years. But the decision to claim early comes with a trade-off for the beneficiary: they get a reduced benefit for a longer period of time. While this "actuarial reduction" decreases the beneficiaries' monthly payment, it is designed to leave the expected present value (EPV) of a worker's lifetime benefits unchanged for those with the average life expectancy. But the key word in the last sentence is average life expectancy. The reductions may not maintain the EPV of the typical member of low socioeconomic status (SES) groups, given that their mortality is above average. This study documents the extent to which this inequality results in low-SES individuals having more incentive to claim early than high-SES workers.

To accomplish this goal, the paper estimates the EPV of Social Security benefits at each possible claiming age (62-70) for various SES groups defined by race and education and identifies the claiming age at which the EPV is the highest. Because the EPV is not a measure of welfare, the results are not intended to suggest what these workers should do. Instead, the goal is to quantify the extent to which some groups have more incentive to delay than others.

Calculating the EPV of Social Security benefits at different claiming ages requires three inputs: 1) interest rates; 2) mortality rates; and 3) lifetime earnings. For the interest rate, the paper tests the sensitivity of results to rates of 1 percent (a likely value given recent trends) and 3 percent (a more traditional long-run level). For the other two inputs, no single dataset contains a large enough sample to accurately estimate mortality rates and lifetime earnings for smaller SES groups. Instead, this paper combines data from two different sources to calculate mortality and lifetime earnings respectively: the National Longitudinal Mortality Study (NLMS) and the Survey of Income and Program Participation (SIPP) linked to administrative W-2 data.

To estimate mortality rates, this paper updates the procedure followed by Brown, Liebman, and Pollet (2002), which used mortality data from 1979-1987, to estimate cohort mortality rates from 2004-2011. This procedure estimates cohort mortality in two steps: 1) the mortality of different SES groups is calculated relative to the average in the NLMS; and 2) these estimates are applied to the average cohort mortality rates maintained by the Social Security Administration (SSA) to obtain an SES-adjusted cohort mortality rate. For SES, the paper uses the same definition as Brown, Liebman, and Pollet and divides people into 12 SES groups - six for each gender. The six groups are: 1) white, less than high school; 2) white, high school 
graduate plus some college; 3) white, completed four years of college; 4) black, less than high school; 5) black, at least high school; and 6) Hispanic.

To calculate lifetime earnings and, ultimately, each SES group's average benefit at each claiming age, the paper uses the SIPP linked to administrative W-2 data made available through the U.S. Census's SIPP Synthetic Beta project. This project allows researchers to access a subset of essential SIPP variables linked, via Social Security number, to an SSA-produced extract from W-2 tax records, including an individual's total Social Security eligible earnings for each year from 1960-2011. 'The study uses these records to estimate respondents' Primary Insurance Amount (PIA) as of age 62 and averages these PIAs within the SES groups. These PIA averages are then used in each groups' EPV calculation.

The findings suggest that, as expected, better-educated SES groups increase their EPV by delaying claiming well past the Early Eligibility Age (EEA) and, for some groups, well past the FRA. Lower SES groups benefit from claiming early. However, the extent of the differences in their EPVs depends on the interest rate assumed: all else equal high rates increase the value of early claiming. If one assumes a 3-percent interest rate, a five-year gap exists between the SES group with the lowest claiming age that maximizes the EPV and the SES group with the highest maximal claiming age, with several groups maximizing the EPV at the EEA of 62. The differences among SES groups are slightly smaller among women, with a gap of four years. At an interest rate of 1 percent, all SES groups have a higher EPV by delaying claiming past age 62 . Of course, variance across groups still exists - for men a gap of four years exists between the group with the earliest maximal claiming age and the highest maximal claiming age and for women that same gap is two years.

The paper also conducts a counterfactual exercise to consider the effect of increasing the early eligibility age to 64 . Pushing back the EEA by two years would cause the least-educated men to claim later than their maximum EPV, but the loss of EPV is just $\$ 3,000$ over their lifetimes. This finding does not necessarily suggest the effect of pushing back the early eligibility age is trivial - workers who claim early are often in poor health and less educated than others, making working longer difficult (Haverstick et al., 2007).

\footnotetext{
${ }^{1}$ The SSB alleviates privacy concerns by allowing researchers to first run their analyses on synthesized data and then, through a U.S. Census employee, re-run the analysis on actual data. The synthetic data aim only to match unconditional means of the public-use SIPP variables, so conditional analysis for selected subsamples is not meaningful. With this consideration, the results reported in this paper are the average of the estimates produced from the Completed Data Files.
} 
The paper is organized as follows. The next section reviews the literature. The following section discusses how mortality estimates are obtained and how lifetime earnings are estimated. The fourth section provides the results. The final section concludes that the inequality in mortality rates among various SES groups results in variations in the age at which the EPV of benefits are maximized and, in some cases, the difference in EPV is non-trivial.

\section{Literature Review}

The literature on Social Security's actuarial reduction has tended to focus on individuals with average mortality. In the 1960s, when the actuarial reduction was introduced, the 20 percent reduction in monthly benefits for claiming at 62 instead of 65 made sense - average life expectancy at 65 was 15 years, so claiming at 62 yielded a 20 percent (3/15) longer benefit receipt period. The size of the reduction for claiming at 62 relative to 65 has remained mostly unchanged, despite the fact that mortality has decreased; in theory, this should mean delaying has become more valuable. But, remarkably, the effectiveness of the actuarial reduction has endured, because interest rates have generally been higher than they were at its inception, making delaying more costly. Jivan (2004) found that the EPV of claiming at 62 was still equal to the EPV of claiming at 65. Munnell and Sass (2012) found that decreasing interest rates between 2004 and 2010 affected this equality, reducing the EPV at 62 to 92 percent of claiming at 65 - still close to 1 but showing some benefit to delay. In any case, an extensive literature has documented a large and growing inequality in mortality, meaning the benefit of delay will be very different for different SES groups.

One of the earliest studies documenting differences in mortality across SES was Kitagawa and Hauser (1973), who defined SES by education, race, income, and other covariates using death records linked to the 1960 Long-Form Census. More recently, in a paper that provides a roadmap for this study's mortality calculations, Brown, Liebman, and Pollet (2002) used NLMS data from the 1980s to show extensive inequality across socioeconomic groups defined by race and education. These studies find blacks and the less educated have shorter life expectancies. Studies that use income instead of race or education come to similar conclusions: Waldron (2013) found an inverse correlation between lifetime earnings and mortality. This inequality means that the EPV of Social Security benefits for some socioeconomic groups will differ by claiming age - for groups with higher-than-average mortality, earlier claiming will produce higher EPVs, with the reverse holding for groups with lower-than-average mortality. 
Furthermore, because inequality in mortality has increased over time, this fact is likely more true today than in the past.

While early studies examining trends in mortality inequality over time found mixed results, more recent studies have tended to find large increases. ${ }^{2}$ For example, Waldron (2007) used lifetime labor market earnings as a measure of SES and found that mortality has declined more rapidly in the top half of the earnings distribution than in the bottom half. Christia (2009) also looks at lifetime earnings - this time in quintiles - and finds substantial increases in lifeexpectancy inequality between 1983 and 2003.

Authors using education as their measure of SES come to similar conclusions. A study by Cutler et al. (2011) examines two educational groups - those with at least some college and everyone else - and found increasing mortality differentials. Bound et al. (2014) examine mortality between 1990 and 2008, and find a large increase in inequality between the bottom and top quartiles. ${ }^{3}$ Bosworth, Burtless, and Zhang (2015) examine rising mortality inequality by both income and relative education for sample members in two relatively small datasets, the HRS and the SIPP. In both samples, and using varying measures of education, they find evidence of rising inequality. Finally, the National Academy of Sciences used the HRS to estimate an increasing relationship between income and mortality between the 1930 and 1960 birth cohorts (National Academy of Sciences, 2015). The whole of this literature makes one thing clear: inequality across SES exists and is getting worse. What does this mean for the EPV of Social Security benefits across SES groups and for various claiming ages?

\section{Empirical Approach}

The EPV of claiming Social Security at a given age is the sum of the individual's annual benefits over his remaining lifetime, discounted by the interest rate and their probability of death. This quantity can be expressed in the following equation:

\footnotetext{
${ }^{2}$ For examples of earlier studies that came to conflicting conclusions, see Rogot, Sorlie, and Johnson (1992), which found little increase in mortality inequality and Pappas et al. (1993), which found widening inequality. ${ }^{3}$ Bound et al. (2014) was a refinement of work by Olshansky et al. (2012), who found an increase in mortality among white high school dropouts between 1990 and 2008. Bound et al. did not find an increase in mortality among the lowest quartile of whites by education and argues the difference is because Olshansky's finding incorporates both rising inequality by SES and the fact that high school dropouts became a more disadvantaged group over the time period studied. Another study finding an increase in mortality around the same period is Case and Deaton (2015), but they focused only on whites aged 45-54.
} 


$$
E P V_{x, c}=\sum_{a=62}^{120} \frac{1}{(1+r)^{a-62}} s_{x, a} S S_{x, c} * I(a \geq c)
$$

where $x$ is the individual's SES group; $c$ is the claiming age being used to calculate the EPV; $r$ is the interest rate; $a$ is the age at which the benefit is received; $s_{x, a}$ is the probability of a person in group $x$ surviving to age $a ; S S_{x, c}$ is the estimated average Social Security benefit of group $x$ claiming at age $c$; and $I(a \geq c)$ indicates whether the benefit has been claimed as of age $a$. Equation (1) calculates the EPV of claiming at various ages for individuals as of age 62. This approach answers the question, "What is the EPV of each potential claiming age for a 62-yearold individual deciding what age to claim?" Calculating the results of equation (1) for individuals making the decision as of each claiming age (e.g., for a 67-year-old deciding to claim at 67) would assume individuals have survived to that age, understating the effect of differential mortality.

Equation (1) makes clear that estimating the EPV of Social Security benefits across SES groups requires: 1) the interest rate; 2) mortality estimates for each group; and 3) estimates of the typical PIA for each group to calculate the benefit at each claiming age. This section describes how the final two components are estimated, with sensitivities for the EPV estimates to various interest rates provided in the results section.

\section{Estimating Mortality by SES}

To estimate mortality by SES for individuals who turn 62 in 2012 (the 1950 birth cohort), this paper follows the methodology of Brown, Liebman, and Pollet (2002) and applies a two-step process. The first step uses the NLMS to calculate annual mortality rates for each SES group relative to the average mortality rate. The NLMS is used for this purpose because it consists of individual-level data from the Current Population Survey (CPS) - which provide data on SES matched to data from death certificates obtained from the National Center for Health Statistics. The data are from 2004-2011, a span of years recent enough to be relevant and long enough to have a reasonable sample size in each SES group. ${ }^{4}$ Table 1 provides the number of observations and deaths in each SES group and makes clear that lower-educated and minority groups have higher average mortality.

\footnotetext{
${ }^{4} 2011$ was the most recent year the NLMS made a link to death certificates, although more recent data will be available in the future.
} 
To estimate the relevant mortality rates, a Census Bureau statistician provided us with tables containing the number of individuals alive in the NLMS at each age and in each SES/gender group between 2004 and 2011. The study calculated age-specific mortality rates using these tables and the following formula:

$$
m_{x, a}=\frac{l_{x, a}-l_{x, a+1}}{l_{x, a}}
$$

where $x$ represents the demographic group and $l$ the number of individuals living at age $a$ from the NLMS sample.

In theory, these rates contain enough information to estimate the relative mortalities, which are each SES/gender group's mortality rates relative to the average mortality rate for that gender. However, even given the use of data across several years, in some age-SES-gender cells the number of deaths is small enough that the estimated mortality rate is non-monotonic with age: at some ages it may appear mortality rates decrease with age even though this does not actually in the population. For this reason, the project fits a non-linear, least squares regression using the Gompertz-Makeham formulation:

$$
q_{x, a}=1-s g^{c^{x, a+1}-c^{x, a}}
$$

where $q_{x, a}$ is the mortality rate for a given SES/gender group at age $a$; $s$ is the age-invariant aspect of mortality (e.g., some groups are more likely to die at any age); and the parameters $g$ and $c$ are group-specific age-mortality profiles. The predictions following this regression are then used to calculate the relative mortality rates of each SES and gender.

For example, Figure 1 illustrates both the raw data and the fitted regression for black men and for the average male, and Figure 2 shows the relative mortalities for black men implied by Figure 1. Figure 1 also illustrates one nice feature of the approach - it uses data from the years prior to age 62 (the EEA) to calculate the mortalities after age 62, since the relationship estimated by the Gompertz-Makeham model applies to all ages in the middle of the life-span. Appendix A contains the estimates of mortality relative to the average at each age from 25 to 100 for each of the 12 SES groups. 
The fitted mortality rates presented in Figure 1 represent "period" estimates of that group's mortality. Period estimates illustrate mortality by age at a given point in time, namely 2004-2011. However, the EPV calculations need to take into account improving mortality - an individual turning 62 in 2012 will turn 72 in 2022 when, presumably, their mortality will be lower than a 72 year old's was in 2012. Such estimates are called "cohort" mortality estimates. To go from a period estimate to a cohort estimate, the project applies the relative mortality for each SES and gender group to that group's average cohort mortality as calculated by the Social Security Administration in 2012.5

As an example of how the calculation works, to estimate cohort mortalities for blacks with at least a high school diploma at age 70, the project multiplies 1.25 (the ratio of their mortality to average male mortality) by 2.5 percent (the mortality rate of the average man according to SSA cohort mortality) to arrive at an estimated cohort mortality rate of 3.2 percent. As Figure 2 indicates, for black men that did not finish high school, the calculation would have a larger adjustment of 1.57 to arrive at a mortality rate of 4.0 percent. Once the adjustments are made for all groups, the project has estimates of cohort mortality that reflect both Social Security's assumptions on mortality improvements in the future and the differences in relative mortality estimated in the NLMS data. These mortality estimates are contained in Appendix B for each SES group. These estimates can be used to calculate the survival probabilities required for equation (1), as illustrated for black men in Figure 3. The estimates can also be used to calculate life expectancies at age 62, as illustrated by Table 2. Not surprisingly, Table 2 shows that life expectancies at 62 are increasing with education. For example, white men with less than a high school degree have age 62 life expectancies that are five years shorter than those with a college degree.

One interesting exercise is to see how life expectancies have changed since Brown, Liebman, and Pollet conducted their analysis with 1980s data. To accomplish this, we re-ran the calculations using the relative mortalities from the Brown, Liebman, and Pollet study and the SSA cohort mortality tables for the 1920 birth cohort - approximately when 62-year-olds in their sample would have been born.

The second column of Table 2 shows how long individuals would be expected to live past age 62 in their sample and illustrates that inequality has increased along the dimension of

\footnotetext{
${ }^{5}$ Note that this assumes that the mortality of blacks and whites improve in the future at the average rate assumed by SSA, although Table 2 suggests that over the last several decades blacks have generally seen faster improvements.
} 
education but has decreased across race. To illustrate this, the third column calculates the change in life expectancy over the 30 years and shows that within each gender the smallest improvements were for white high school dropouts, while white college graduates and blacks with at least a high school degree saw the largest gains. For white women who dropped out of high school, the study actually finds a very slight decrease in life expectancy. However, when viewing these results, it is important to remember that over the 30 years considered, the group of high school dropouts shrank considerably. This fact means that some of the rise in inequality may be because this SES group became increasingly disadvantaged over time.

\section{Estimating Primary Insurance Amounts by SES}

The second piece needed to calculate the EPV of claiming at different ages is the expected Social Security benefit of each gender and SES group at each claiming age. To estimate this quantity, the paper uses data from the SIPP linked to administrative W-2 data from 1960 to 2011 through the SIPP Synthetic Beta Project (SSB). The SSB allows researchers to write computer code that estimates a desired quantity on synthetic earnings data and then provide that code to a Census researcher to run on administrative $\mathrm{W}-2$ data. This paper presents results based on the actual W-2 data.

The analysis is restricted to individuals turning 62 between 2004 and 2011 and calculates their PIA as of age 62 based on their highest 35 years of actual reported earnings adjusted using the average wage index. ${ }^{6}$ The sample also includes only individuals who would qualify for a Social Security retirement benefit, i.e., individuals whose FICA earnings exceeded the amount required to receive a quarter of coverage credit in at least 10 years. The benefit at any claiming age is then simply the PIA adjusted by whatever actuarial adjustment would apply. This calculation implicitly assumes that individuals claiming after age 62 either: 1) do not work and, thus, do not accrue additional years of earnings that could affect their benefits; or 2) they do work but any additional year yields earnings low enough that they do not factor into the top 35 years of earnings. While this is a simplifying assumption, average earnings after age 62 are lower than during workers' primes (Reznick, Weaver, and Biggs 2009).

For purposes of this calculation, the PIA for each man or woman is calculated based on their own earnings and ignores the fact that in some cases they may qualify for a spousal benefit.

\footnotetext{
${ }^{6} 2011$ was the last year the SIPP was linked to administrative W-2 records.
} 
Once the PIA is calculated for each individual in the SIPP sample, the average is taken within each SES group to come up with the PIA used to calculate Social Security benefits at each claiming age as required by equation (1). Table 3 contains the estimated PIAs for each gender and SES group. As expected, Table 3 shows that the PIAs of men are higher than those of women with comparable educations and that PIAs within each racial/gender group are increasing with education.

\section{Results}

Calculating the EPV of the Social Security benefit requires the estimates of mortality and the PIA described above, but also an estimate of interest rates. Because it is unclear which interest rate will prevail in the future, this section presents the results of the analysis under two scenarios: 1) 1 percent to reflect the current level; and 2) 3 percent to reflect a more typical situation. The section first presents an analysis of the claiming age that maximizes the EPV of benefits for each SES group and then discusses what the results mean for policies such as increasing the EEA to 64.

\section{Claiming Ages that Maximize the EPV of Social Security Benefits}

Equation (1) is used for each claiming age from 62 to 70 to calculate the point at which each SES group maximizes the EPV of its Social Security benefits. Increasing the claiming age by a year has offsetting effects, since each year of delay increases the EPV through a larger monthly benefit but also reduces the EPV for two reasons: 1) the individual is less likely to survive to receive the benefit at all, and if it is received, the length of time is shorter; and 2) the amount is discounted by the interest rate. The contention of this paper is that the mortality effect will cause different SES groups to have different ages that maximize the EPV of their benefits.

Table 4 shows the estimates for equation (1) for all 12 SES/gender groups for claiming ages 62 to 70 and highlights the age maximizing the EPV of benefits. The results show that the higher mortality of blacks and whites with less than a high school diploma means that they maximize the EPV of benefits by claiming earlier. Under a 1-percent assumed interest rate when delaying makes more sense than under a 3-percent rate - the claiming age at which the EPV is maximized for white men ranges from 65 to 69 . For blacks the range is smaller, from 67 
to $68 .^{7}$ Hispanics actually look more like college-educated white males, with the maximum age at 69. The reason is that when examining U.S. datasets like the NLMS, Hispanics actually have relatively low mortality, a fact referred to in the literature as the Hispanic mortality paradox. ${ }^{8}$ Under an interest rate of 1 percent, the maximum EPV of women is typically fairly late - the lowest maximal EPV claiming age is 68 .

Under an assumed interest rate of 3 percent, the highest EPV for several male groups is actually at age 62- when delaying is more costly. Compare this result to white male college graduates, whose EPV is maximized at 67 even under the 3-percent rate assumption. For women, the results are similar with smaller magnitudes. Several low-SES groups maximize the EPV of their benefits by claiming at 64 , while white female college graduates maximize benefits at age 68. Again, Hispanic men and women are most comparable to white college graduates.

Still, while the difference in the ages at which the EPVs are maximized can appear quite large, the differences in the values of the EPVs across claiming ages are modest. Figures 4A to 4B show the ratios of the EPV at each claiming age to the maximum EPV s each male SES group could receive. Figure 4A does the calculation for whites at interest rates of 1 and 3 percent, respectively, and Figure 4B does the same for blacks and Hispanics. Figures 4C and 4D show the same estimates for women. The results show that, regardless of the claiming age or SES, the EPV of benefits falls within 16 percent of the maximum level.

Even though differences in the EPVs are modest, interesting variations do exist. At an interest rate of 1 percent, white, female college graduates would decrease their EPVs by 16 percent if they claimed at 62 (EPV of \$277,400) instead of their maximum EPV age of 70 $(\$ 321,200)$. Compare this result to white females with some college who decrease their EPVs by 10 percent by claiming at $62(\$ 205,100)$, since their maximum claiming age is $69(\$ 230,100)$. And at an interest rate of 3 percent, some groups clearly have higher EPVs when claiming well before their FRAs. The most glaring example of this finding is white high school dropouts whose EPV of benefits is highest if they claim at age $62(\$ 163,100)$ and decreases by 13 percent if they delay claiming all the way to $70(\$ 141,900)$.

\footnotetext{
${ }^{7}$ Somewhat counterintuitively, white men with the same level of education have a lower maximal claiming age. This occurs because even though black men with less than a high school degree have higher mortality than whites over much of their lives, blacks after age 62 have slightly lower mortality and slightly longer life expectancies - see Table 2.

${ }^{8}$ Although it is somewhat unclear whether Hispanic mortality is actually lower or if it is a data quality issue, for example, because unhealthy Hispanics return to their home countries and drop out of the data used for analyses like this one. For a discussion of this issue, see Turra et al. (2008).
} 


\section{Pushing the EEA Back to 64}

The data in Table 4 can be used to determine which groups would lose out on expected benefits if they were forced to claim no earlier than age $64 .{ }^{9}$ As is implied by the discussion above, less educated males are the most affected, but the differences are small and only appear when the assumed interest rate is 3 percent. For white high school dropouts, pushing the EEA back to 64 would cost them less than $\$ 3,000$ in EPV since claiming at 64 results in an EPV of $\$ 160,500$ in benefits but claiming at 62 is an EPV of $\$ 163,100$. For black high school dropouts, a similarly small difference exists, with a reduction in EPV from $\$ 139,900$ to $\$ 137,800$. For the other 10 SES groups, claiming at 64 has a similar or higher EPV than claiming at 62 . Policies that increase the EEA may have other detrimental effects, for example, eliminating the only source of income some workers have should they be forced to retire before they can claim. But the policy would not significantly reduce the expected lifetime value of benefits for any SES group.

\section{Conclusion}

The actuarial reduction in monthly benefits is meant to equate the expected present value of Social Security retirement benefits no matter when a worker claims them. This equality is meant to hold for the average worker. But for disadvantaged SES groups - who tend to have higher mortality than average - the expected value of benefits could be higher when claiming early, while high SES groups benefit from delay. Indeed, this paper shows that the gap between claiming ages that maximize the EPV can be as large as 5 years for men and 4 years for women.

At the same time, the differences in EPVs between earlier and later claiming are modest. Within SES groups, the largest difference that exists between the lowest and highest EPV of benefits is 16 percent for female college graduates: if they claim at 70, their EPV is $\$ 321,200$ dollars, but if they claim early at 62 , it is just $\$ 277,400$ dollars. The results highlight that members of different SES groups face different claiming incentives, due to inequality in mortality. Low-SES groups have more incentive to claim early, while high-SES groups have an extra incentive to delay. While this research does not suggest that low-SES individuals should

\footnotetext{
${ }^{9}$ An extensive literature exists on the effects of pushing back Social Security's EEA to 64. For example, Olsen (2012) explores the distributional effects of raising the FRA only or the raising the EEA and FRA in tandem. Gustman and Steinmeier (2005) explore the effects on retirement timing of increasing the EEA from 62 to 64 . And Vinkenes et al. (2007) discuss the various policy issues that would need to be addressed were the EEA actually increased.
} 
claim their Social Security benefits as early as possible - after all, the EPV is not a measure of welfare - it quantifies the extent to which their higher mortality rates diminish the gains of delay. 


\section{References}

Brown, J., J. B. Liebman, \& J. Pollet. 2002. “Appendix: Estimating Life Tables that Reflect Socioeconomic Differences in Mortality." In The Distributional Aspects of Social Security and Social Security Reform, edited by M. Feldstein and J. B. Liebman, 447-457. Chicago, IL: University of Chicago Press.

Bosworth, B., G. Burtless, and K. Zhang. 2015. "Sources of Increasing Differential Mortality among the Aged by Socioeconomic Status." Working Paper 2015-10. Chestnut Hill, MA.

Bound, J., A. Geronimus, J. Rodriguez, and T. Waidmann. 2014. "The Implications of Differential Trends in Mortality for Social Security Policy." Paper Presented at $16^{\text {th }}$ Annual Meeting of the Retirement Research Consortium. Washington, DC.

Case, A. and Angus Deaton. 2015. "Rising Morbidity and Mortality in Midlife among White Non-Hispanic Americans in the 21st Century" Proceedings of the National Academy of Sciences 112(49): 15078-15083.

Cristia, J. P. 2009. "Rising Mortality and Life Expectancy Differentials by Lifetime Earnings in the United States.” Journal of Health Economics 28(5): 984-995.

Cutler, D. M., F. Lange, E. Meara, S. Richards-Shubik, and C. J. Ruhm. 2011. "Rising Educational Gradients in Mortality: The Role of Behavioral Risk Factors.” Journal of Health Economics 30(6): 1174-1187.

Gompertz, B. 1825. "On the Nature of the Function Expressive of the Law of Human Mortality and on a New Mode of Determining the Value of Life Contingencies." Philosophical Transactions of the Royal Society of London 115: 513-585.

Gustman, Alan L. and Thomas L. Steinmeier. 2005. "The Social Security Early Entitlement Age in a Structural Model of Retirement and Wealth." Journal of Public Economics 89(2): 441-463.

Haverstick, Kelly, Margarita Sapozhnikov, Robert Triest, and Natalia Zhivan. 2007. "A New Approach to Raising Social Security's Earliest Eligibility Age.” Working Paper 2007-10. Chestnut Hill, MA: Center for Retirement Research at Boston College.

Jivan, N. 2004. "How Can the Actuarial Reduction for Social Security Early Retirement Be Right?" Just the Facts Issue in Brief 11. Chestnut Hill, MA: Center for Retirement Research at Boston College.

Kitagawa, E. M. and P. M. Hauser. 1973. Differential Mortality in the United States: A Study in Socioeconomic Epidemiology. Cambridge, MA: Harvard University Press.

Lee, R. D. and L. R. Carter. 1992. "Modeling and Forecasting U.S. Mortality.” Journal of American Statistical Association 87(419): 659-671 
Munnell, Alicia H. and Steve A. Sass. 2012. "Can the Actuarial Reduction for Social Security Early Retirement Still Be Right?” Issue in Brief 12-6. Chestnut Hill, MA: Center for Retirement Research at Boston College.

National Academies of Sciences, Engineering, and Medicine. 2015. "The Growing Gap in Life Expectancy by Income: Implications for Federal Programs and Policy Responses." Washington, DC: The National Academies Press.

Olsen, Anya. 2012. "Mind the Gap: The Distributional Effect of Raising the Early Eligibility Age and the Full Retirement Age." Social Security Bulletin 72(4): 37-46.

Olshansky, S. J., T. Antonucci, L. Berkman, R. H. Binstock, A. Boersch-Supan, J. T. Cacioppo, B. A. Carnes, L. L. Carstensen, L. P. Fried, D. P. Goldman, J. Jackson, M. Kohli, J. Rother, Y. Zheng, and J. Rowe. 2012. "Differences in Life Expectancy Due to Race and Educational Differences Are Widening, and Many May Not Catch Up.” Health Affairs 31(8): 1803-1813.

Reznick, Gayle L., David A. Weaver, and Andrew G. Biggs. 2009. "Social Security and Marginal Returns to Work Near Retirement.” Social Security Bulletin 2009-02: 1-19.

Turra, C. M. and I. T. Elmo. 2008. "The Impact of Salmon Bias on the Hispanic Mortality Advantage." Population Research and Policy Review 27(5): 515-530.

U.S. Census Bureau. 2015. SIPP Synthetic Beta: Version 6.0 [computer file]. Washington, DC; Cornell University, Synthetic Data Server [distributor], Ithaca, NY.

U.S. Census Bureau, National Heart, Lung, and Blood Institute, National Cancer Institute, National Institute on Aging, National Center for Health Statistics. National Longitudinal Mortality Study Microdata Version 5, 2004-2011 [Computer file]. Washington, DC.

U.S. Census Bureau. 2015. SIPP Synthetic Beta Version 6.0.2 [producer] and Cornell University, Synthetic Data Server [distributor], Washington, DC and Ithaca, NY [Computer file].

Vinkenes, Pat, Alice Wade, Mark Sarney, and Tim Kelly. 2007. "Considerations for Potential Proposals to Change the Earliest Eligibility Age for Retirement." Policy Brief 2007-01. Washington, DC: U.S. Social Security Administration.

Waldron, H. 2007. "Trends in Mortality Differentials and Life Expectancy for Male Social Security-covered Workers, by Socioeconomic Status.” Social Security Bulletin 67(3): 128.

. 2013. "Mortality Differentials by Lifetime Earnings Decile: Implications for Evaluations of Proposed Social Security Law Changes.” Social Security Bulletin 73(1): 1-37. 
Figure 1. Raw and Gompertz-Makeham Smoothed Mortality Rates for Non-Hispanic, African American Men, Ages 25-85

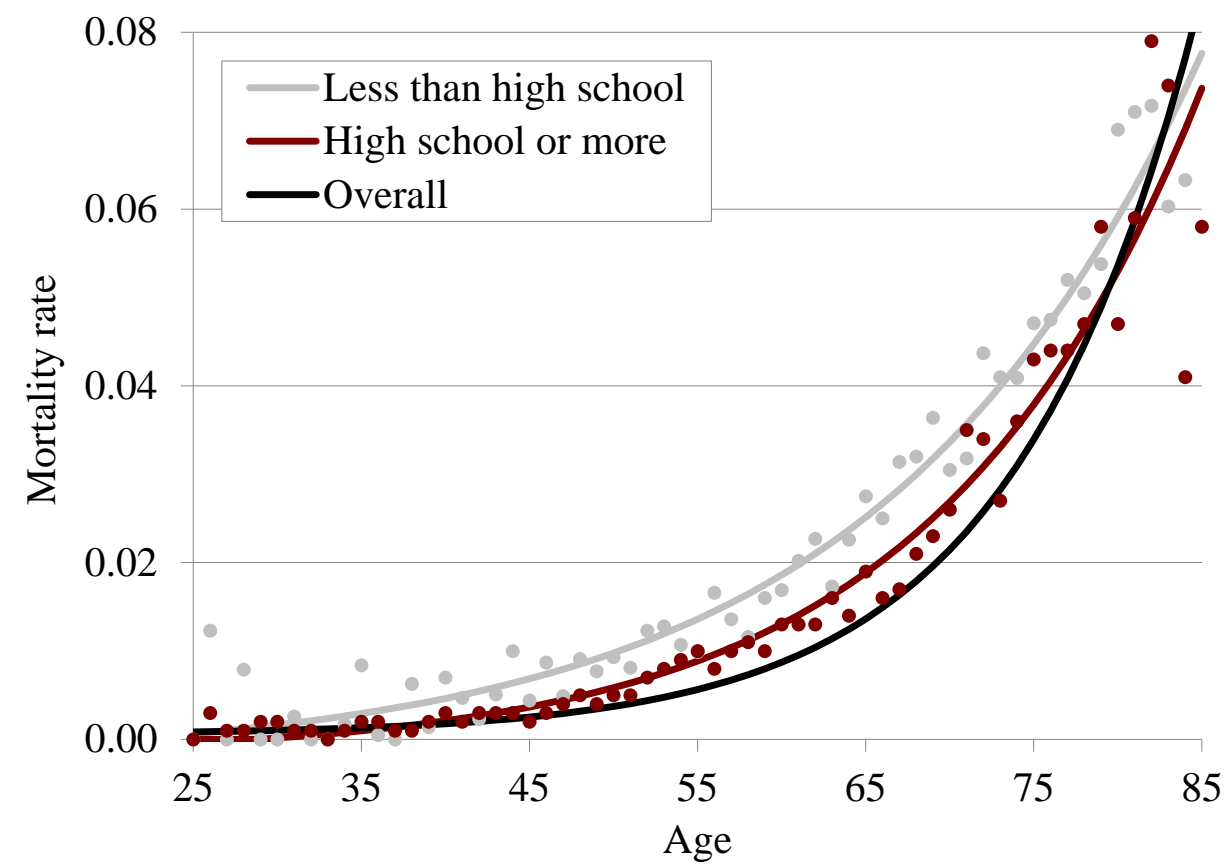

Source: Authors' calculations based on restricted National Longitudinal Mortality Study (NLMS) data provided by the U.S. Census.

Figure 2. Relative Mortality Rates for Non-Hispanic, African American Men to the National Average Mortality Rate for All Men, Ages 25-85

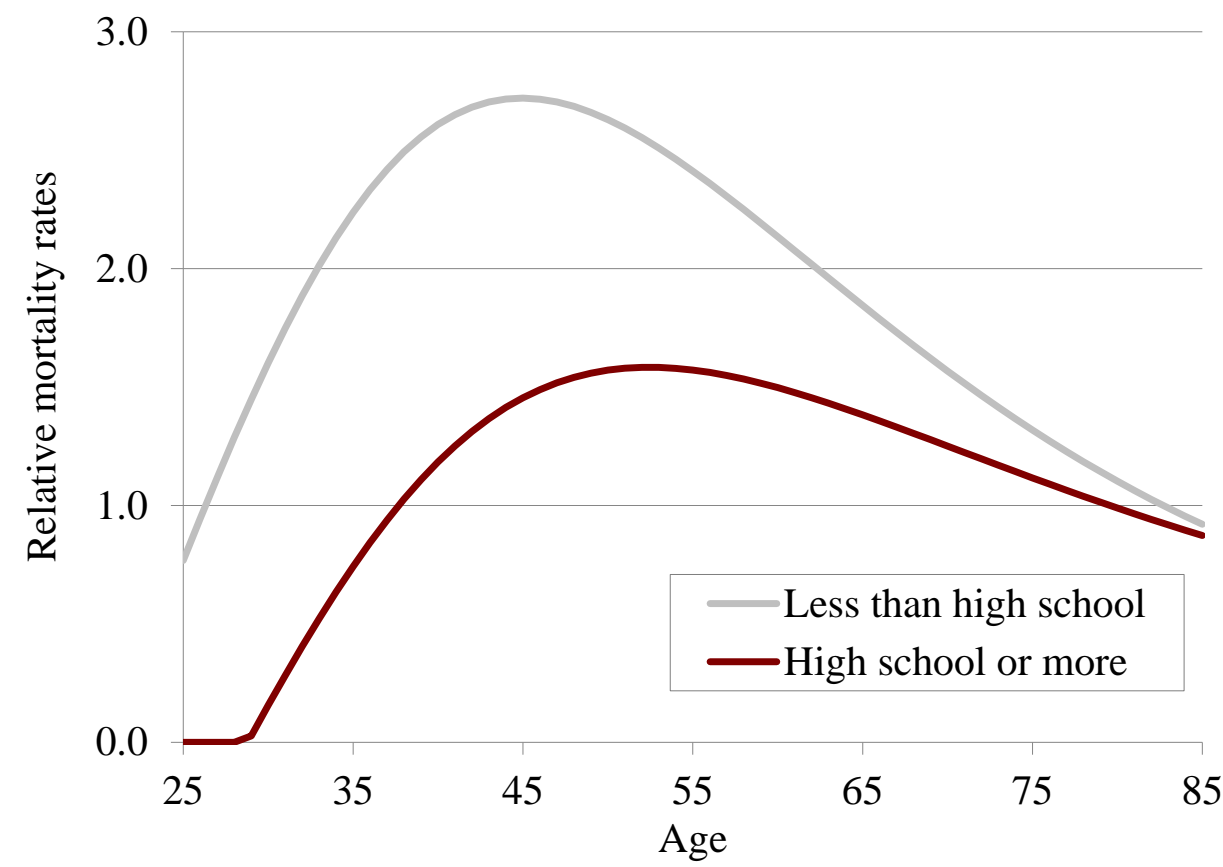

Source: Authors' calculations based on restricted NLMS data provided by the U.S. Census. 
Figure 3. Survival Rates of Non-Hispanic, African American Men at Age 62

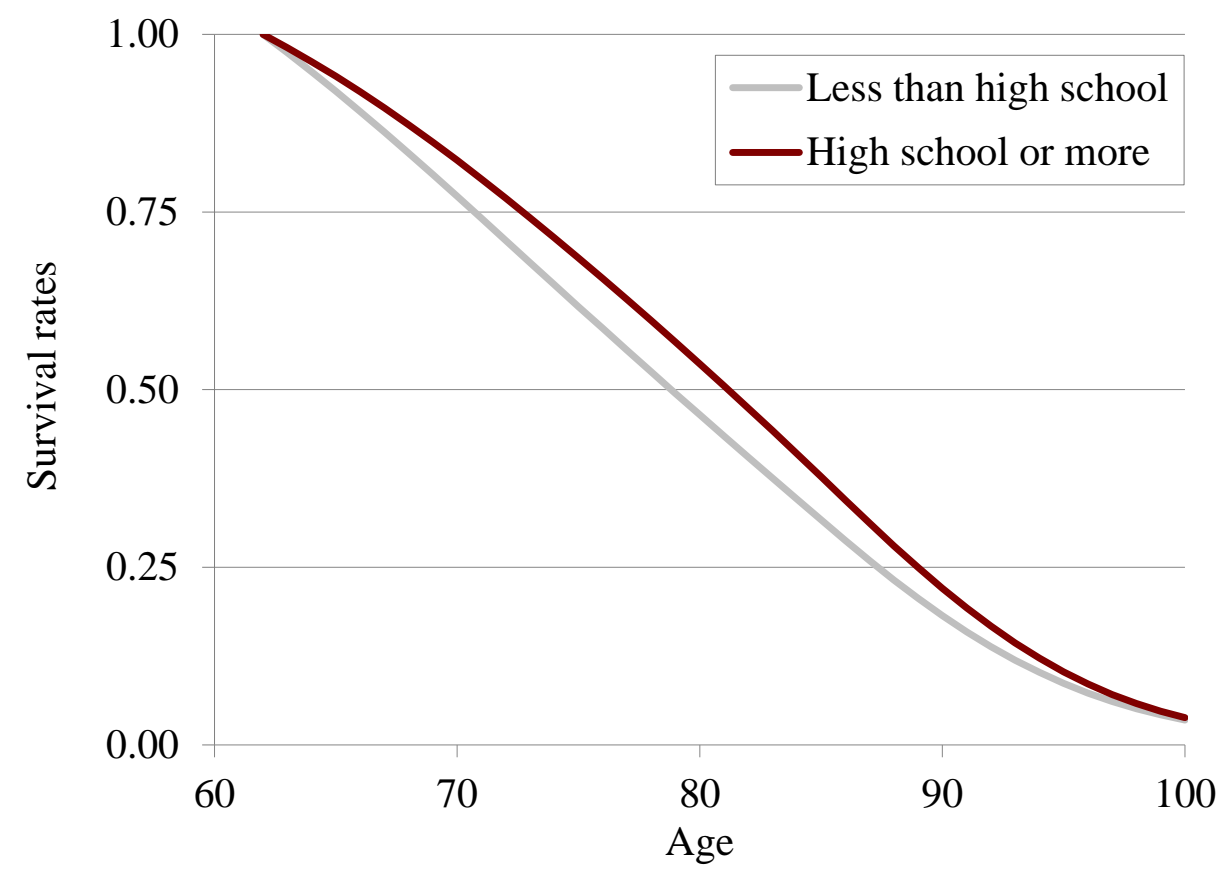

Sources: Authors' calculations based on restricted NLMS data provided by the U.S. Census and 1950 Birth Cohort Mortality Rates from the Social Security Administration. 
Figure 4. Ratio of the SSA Lifetime Benefit to Maximum Benefit by Claiming Age, Gender, Race/Ethnicity, and Educational Attainment

1\% Interest Rate Assumption 3\% Interest Rate Assumption

A. Non-Hispanic white men
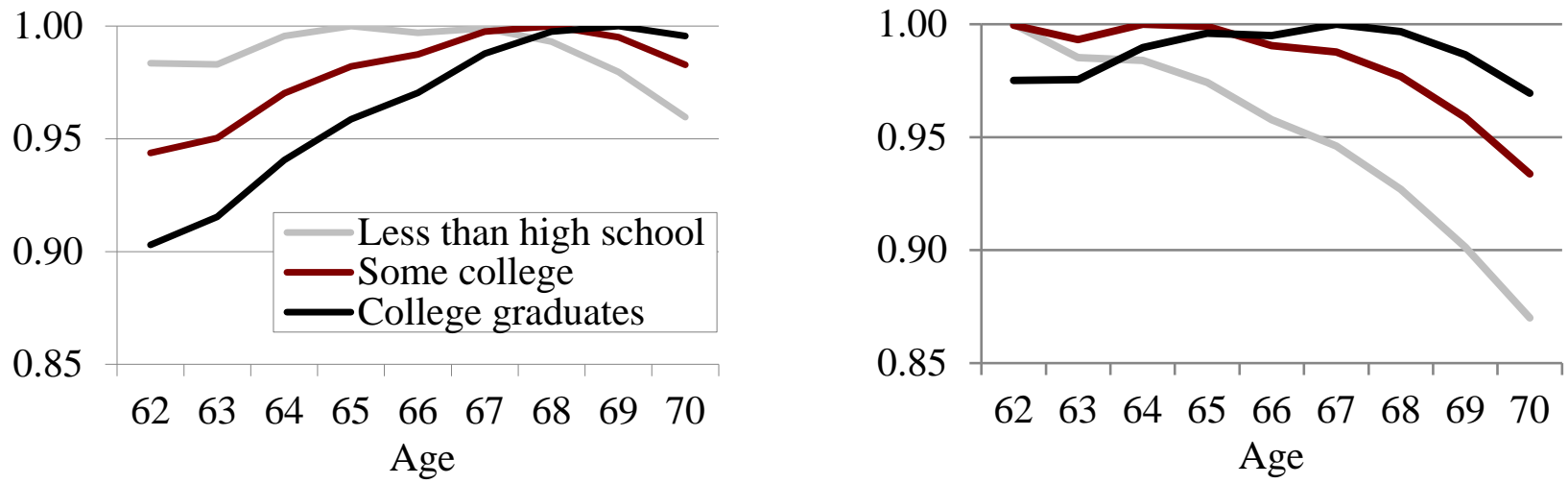

$\begin{array}{lllllllll}62 & 63 & 64 & 65 & 66 & 67 & 68 & 69 & 70\end{array}$ Age

B. Black men by education and Hispanic men
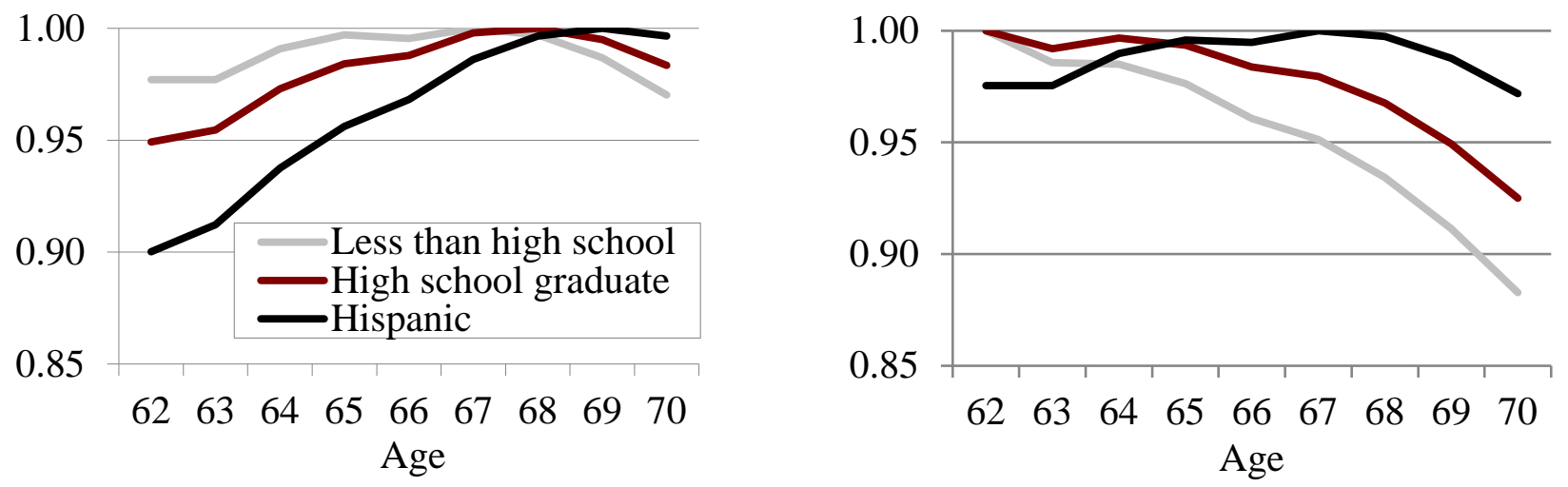

C. Non-Hispanic white women
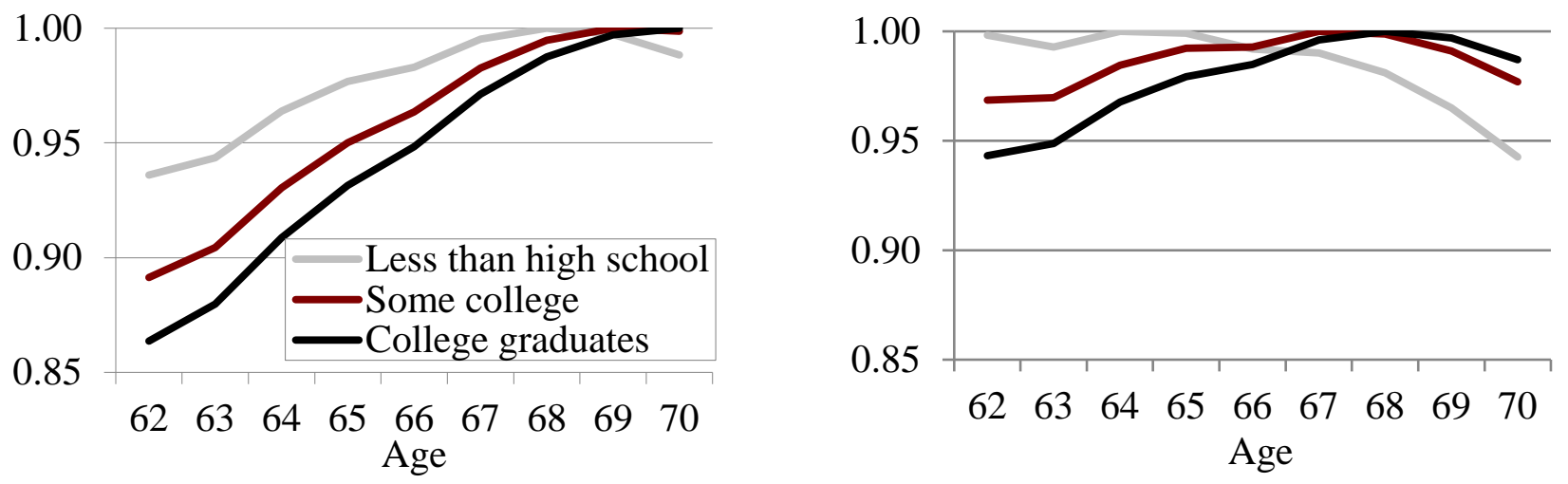
D. Black women by education and Hispanic women
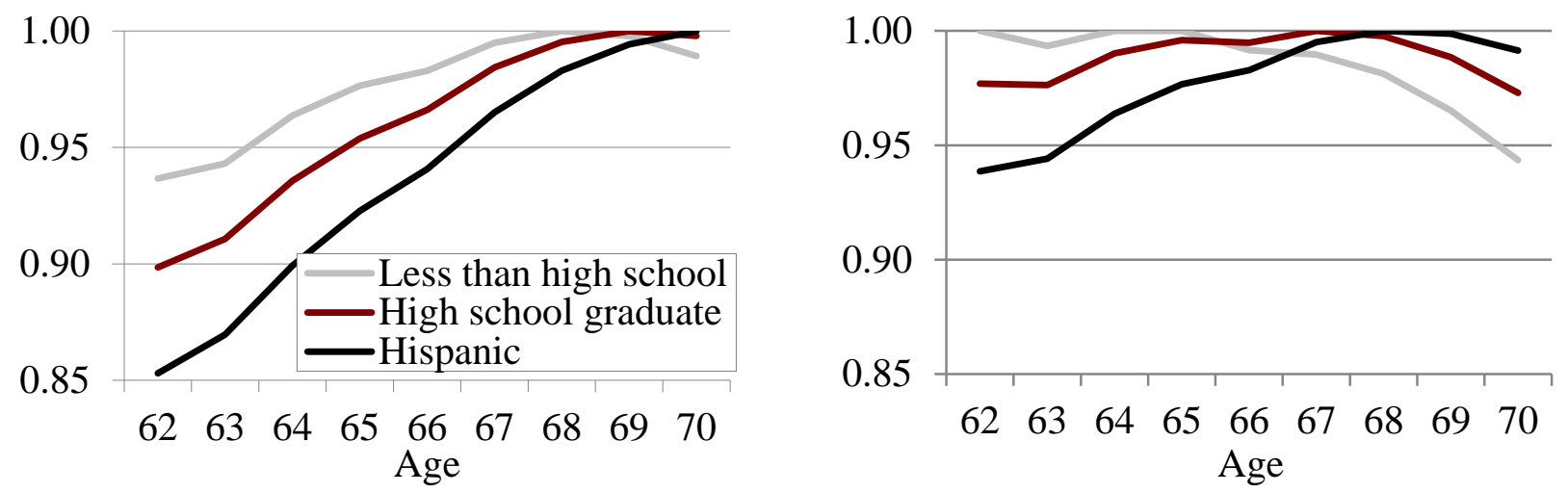

Sources: Authors' calculations based on restricted NLMS data provided by the U.S. Census, 1950 Birth Cohort Mortality Rates from the U.S. Social Security Administration, and the U.S. Census and Cornell University Survey of Income and Program Participation. 
Table 1. Number of Deaths, Observations, and Mortality Rates by Gender, Race/Ethnicity, and Educational Attainment Groups for those Aged 25-84, 2004-2011

\begin{tabular}{|c|c|c|c|c|c|}
\hline Gender & $\begin{array}{l}\text { Race/ } \\
\text { ethnicity }\end{array}$ & Education & $\begin{array}{c}\text { Total number } \\
\text { of deaths }\end{array}$ & $\begin{array}{l}\text { Person-year } \\
\text { observations }\end{array}$ & $\begin{array}{c}\text { Overall } \\
\text { mortality rate }\end{array}$ \\
\hline \multirow{6}{*}{ Men } & \multirow{3}{*}{ White } & Less than high school & 10,437 & 386,902 & 0.0270 \\
\hline & & High school/some college & 24,048 & $2,048,772$ & 0.0117 \\
\hline & & Bachelors and more & 7,953 & $1,111,940$ & 0.0072 \\
\hline & \multirow{2}{*}{ Black } & Less than high school & 2,163 & 84,863 & 0.0255 \\
\hline & & High school or more & 3,133 & 297,583 & 0.0105 \\
\hline & \multicolumn{2}{|c|}{ Hispanic } & 3,481 & 579,539 & 0.0060 \\
\hline \multirow{6}{*}{ Women } & \multirow{3}{*}{ White } & Less than high school & 9,227 & 418,168 & 0.0221 \\
\hline & & High school/some college & 23,366 & $2,528,067$ & 0.0092 \\
\hline & & Bachelors and more & 4,094 & 988,550 & 0.0041 \\
\hline & \multirow{2}{*}{ Black } & Less than high school & 2,538 & 122,342 & 0.0207 \\
\hline & & High school or more & 3,314 & 428,614 & 0.0077 \\
\hline & \multicolumn{2}{|c|}{ Hispanic } & 2,820 & 647,208 & 0.0044 \\
\hline
\end{tabular}

Source: Authors' calculations based on restricted NLMS data provided by the U.S. Census. 
Table 2. Life Expectancy at Age 62 by Gender, Race/Ethnicity, and Educational Attainment

\begin{tabular}{|c|c|c|c|c|c|}
\hline \multirow[b]{2}{*}{ Gender } & \multirow[b]{2}{*}{$\begin{array}{l}\text { Race/ } \\
\text { ethnicity }\end{array}$} & \multicolumn{3}{|c|}{ Life expectancy at 62} & \multirow[b]{2}{*}{ Change } \\
\hline & & Education & $\begin{array}{c}\text { Current } \\
\text { differentials } \\
(1950 \text { birth cohort })(19\end{array}$ & $\begin{array}{l}\text { Brown et al. } \\
\text { differentials } \\
20 \text { birth cohort) }\end{array}$ & \\
\hline \multirow{6}{*}{ Men } & \multirow{3}{*}{ White } & Less than high school & 16.6 & 15.1 & 1.5 \\
\hline & & High school/some college & 19.1 & 16.5 & 2.6 \\
\hline & & College grads & 21.7 & 18.2 & 3.5 \\
\hline & \multirow{2}{*}{ Black } & Less than high school & 17.0 & 13.0 & 4.0 \\
\hline & & High school or more & 18.6 & 14.4 & 4.2 \\
\hline & Hispanic & & 21.8 & 18.7 & 3.1 \\
\hline \multirow{6}{*}{ Women } & \multirow{3}{*}{ White } & Less than high school & 19.4 & 19.5 & -0.1 \\
\hline & & High school/some college & 22.3 & 20.7 & 1.6 \\
\hline & & College grads & 24.3 & 21.7 & 2.6 \\
\hline & \multirow{2}{*}{ Black } & Less than high school & 19.3 & 17.4 & 1.9 \\
\hline & & High school or more & 21.7 & 19.2 & 2.5 \\
\hline & Hispanic & & 25.0 & 21.9 & 3.1 \\
\hline
\end{tabular}

Sources: Authors' calculations based on restricted NLMS data provided by the U.S. Census, 1950 and 1920 Birth Cohort Mortality Rates from the Social Security Administration, and Brown, Liebman, and Pollet (2002).

Table 3. Primary Insurance Amount by Gender, Race/Ethnicity, and Educational Attainment, 2004-2011.

\begin{tabular}{|c|c|c|c|}
\hline Gender & $\begin{array}{l}\text { Race/ } \\
\text { ethnicity }\end{array}$ & Education & $\begin{array}{c}\text { Primary insurance } \\
\text { amount }\end{array}$ \\
\hline \multirow{6}{*}{ Men } & \multirow{3}{*}{ White } & Less than high school & $\$ 16,500$ \\
\hline & & High school/some college & 20,000 \\
\hline & & College grads & 22,600 \\
\hline & \multirow{2}{*}{ Black } & Less than high school & 14,100 \\
\hline & & High school or more & 17,400 \\
\hline & Hispanic & & 15,700 \\
\hline \multirow{6}{*}{ Women } & \multirow{3}{*}{ White } & Less than high school & 10,100 \\
\hline & & High school/some college & 13,300 \\
\hline & & College grads & 16,600 \\
\hline & \multirow{2}{*}{ Black } & Less than high school & 9,700 \\
\hline & & High school or more & 14,100 \\
\hline & Hispanic & & 11,500 \\
\hline
\end{tabular}

Source: Tabulations provided by U.S. Census Bureau and Cornell University, Survey of Income and Program Participation. 
Table 4. Expected Present Value of Lifetime SSA Benefits by Claiming Age, Gender, Racer/Ethnicity, and Educational Attainment, in Thousands

\begin{tabular}{|c|c|c|c|c|c|c|c|c|c|c|c|}
\hline & & & \multicolumn{9}{|c|}{$1 \%$ interest rate assumption } \\
\hline Gender & $\begin{array}{l}\text { Race/ } \\
\text { ethnicity }\end{array}$ & Education & 62 & 63 & 64 & 65 & 66 & 67 & 68 & 69 & 70 \\
\hline \multirow{6}{*}{ Men } & \multirow{3}{*}{ White } & Less than high school & $\$ 197.2$ & $\$ 197.1$ & $\$ 199.6$ & $\$ 200.5$ & $\$ 199.9$ & $\$ 200.3$ & $\$ 199.1$ & $\$ 196.4$ & $\$ 192.4$ \\
\hline & & HS/some college & 270.0 & 271.9 & 277.6 & 281.0 & 282.5 & 285.4 & 286.1 & 284.7 & 281.2 \\
\hline & & College grads & 341.5 & 346.2 & 355.7 & 362.6 & 367.0 & 373.6 & 377.3 & 378.2 & 376.5 \\
\hline & \multirow{2}{*}{ Black } & Less than high school & 170.5 & 170.5 & 172.9 & 174.0 & 173.7 & 174.5 & 174.0 & 172.2 & 169.3 \\
\hline & & High school or more & 228.0 & 229.3 & 233.7 & 236.4 & 237.3 & 239.7 & 240.2 & 239.0 & 236.2 \\
\hline & \multicolumn{2}{|c|}{ Hispanic } & 238.0 & 241.2 & 247.9 & 252.8 & 256.0 & 260.7 & 263.5 & 264.4 & 263.5 \\
\hline \multirow{7}{*}{ Women } & \multirow{3}{*}{ White } & Less than high school & 137.5 & 138.6 & 141.6 & 143.5 & 144.4 & 146.2 & 146.9 & 146.5 & 145.2 \\
\hline & & HS/some college & 205.1 & 208.1 & 214.1 & 218.6 & 221.7 & 226.1 & 228.9 & 230.1 & 229.8 \\
\hline & & College grads & 277.4 & 282.6 & 291.9 & 299.2 & 304.6 & 312.0 & 317.2 & 320.3 & 321.2 \\
\hline & \multirow{2}{*}{ Black } & Less than high school & 131.6 & 132.5 & 135.4 & 137.2 & 138.1 & 139.8 & 140.5 & 140.2 & 139.0 \\
\hline & & High school or more & 212.3 & 215.2 & 221.1 & 225.4 & 228.3 & 232.6 & 235.2 & 236.3 & 235.8 \\
\hline & \multicolumn{2}{|c|}{ Hispanic } & 195.5 & 199.3 & 206.1 & 211.5 & 215.6 & 221.2 & 225.3 & 227.9 & 229.2 \\
\hline & & & & & & $\%$ intere & st rate a & sumptior & & & \\
\hline \multirow{6}{*}{ Men } & \multirow{3}{*}{ White } & Less than high school & $\$ 163.1$ & $\$ 160.7$ & $\$ 160.5$ & $\$ 158.9$ & $\$ 156.2$ & $\$ 154.3$ & $\$ 151.2$ & $\$ 147.0$ & $\$ 141.9$ \\
\hline & & HS/some college & 220.3 & 218.9 & 220.4 & 220.2 & 218.3 & 217.7 & 215.3 & 211.3 & 205.8 \\
\hline & & College grads & 274.7 & 274.8 & 278.8 & 280.6 & 280.3 & 281.7 & 280.8 & 277.9 & 273.1 \\
\hline & \multirow{2}{*}{ Black } & Less than high school & 139.9 & 137.9 & 137.8 & 136.6 & 134.4 & 133.1 & 130.7 & 127.5 & 123.5 \\
\hline & & High school or more & 185.4 & 183.9 & 184.8 & 184.2 & 182.4 & 181.6 & 179.4 & 176.0 & 171.5 \\
\hline & \multicolumn{2}{|c|}{ Hispanic } & 190.6 & 190.6 & 193.4 & 194.6 & 194.4 & 195.4 & 194.9 & 193.0 & 189.9 \\
\hline \multirow{6}{*}{ Women } & \multirow{3}{*}{ White } & Less than high school & 111.3 & 110.7 & 111.5 & 111.4 & 110.6 & 110.4 & 109.4 & 107.6 & 105.1 \\
\hline & & HS/some college & 163.4 & 163.6 & 166.1 & 167.4 & 167.5 & 168.7 & 168.5 & 167.2 & 164.8 \\
\hline & & College grads & 219.2 & 220.5 & 224.9 & 227.6 & 228.9 & 231.5 & 232.4 & 231.7 & 229.4 \\
\hline & \multirow{2}{*}{ Black } & Less than high school & 106.3 & 105.6 & 106.3 & 106.3 & 105.4 & 105.2 & 104.3 & 102.6 & 100.3 \\
\hline & & High school or more & 169.3 & 169.2 & 171.6 & 172.6 & 172.4 & 173.3 & 172.9 & 171.3 & 168.6 \\
\hline & \multicolumn{2}{|c|}{ Hispanic } & 153.0 & 153.9 & 157.1 & 159.2 & 160.2 & 162.2 & 163.0 & 162.8 & 161.6 \\
\hline
\end{tabular}

Sources: Authors' calculations based on restricted NLMS data provided by the U.S. Census, 1950 Birth Cohort Mortality Rates from the Social Security Administration, and the U.S. Census and Cornell University Survey of Income and Program Participation. 
Appendix A1. Male Mortality Rates by Race/Ethnicity and Education Relative to the Average

\begin{tabular}{|c|c|c|c|c|c|c|}
\hline \multirow[b]{2}{*}{ Age } & \multicolumn{3}{|c|}{ White } & \multicolumn{2}{|c|}{ Black } & \multirow[b]{2}{*}{ Hispanic } \\
\hline & $\begin{array}{c}\text { Less than } \\
\text { high school }\end{array}$ & $\begin{array}{l}\text { HS/some } \\
\text { college }\end{array}$ & $\begin{array}{c}\text { College } \\
\text { grads }\end{array}$ & $\begin{array}{c}\text { Less than } \\
\text { high school }\end{array}$ & $\begin{array}{l}\text { High school } \\
\text { or more }\end{array}$ & \\
\hline 25 & 1.75791 & 1.43036 & 0.52194 & 0.76807 & -- & 1.03828 \\
\hline 26 & 1.80670 & 1.41601 & 0.51334 & 0.94562 & -- & 1.02036 \\
\hline 27 & 1.85411 & 1.40133 & 0.50477 & 1.11877 & -- & 1.00218 \\
\hline 28 & 1.89980 & 1.38639 & 0.49631 & 1.28652 & -- & 0.98382 \\
\hline 29 & 1.94346 & 1.37123 & 0.48799 & 1.44792 & 0.02720 & 0.96538 \\
\hline 30 & 1.98478 & 1.35594 & 0.47989 & 1.60206 & 0.15640 & 0.94695 \\
\hline 31 & 2.02348 & 1.34056 & 0.47207 & 1.74810 & 0.28243 & 0.92861 \\
\hline 32 & 2.05931 & 1.32518 & 0.46458 & 1.88528 & 0.40464 & 0.91047 \\
\hline 33 & 2.09202 & 1.30987 & 0.45749 & 2.01293 & 0.52240 & 0.89261 \\
\hline 34 & 2.12143 & 1.29468 & 0.45084 & 2.13051 & 0.63516 & 0.87513 \\
\hline 35 & 2.14738 & 1.27969 & 0.44469 & 2.23759 & 0.74242 & 0.85811 \\
\hline 36 & 2.16974 & 1.26495 & 0.43909 & 2.33384 & 0.84374 & 0.84164 \\
\hline 37 & 2.18845 & 1.25054 & 0.43409 & 2.41909 & 0.93878 & 0.82577 \\
\hline 38 & 2.20346 & 1.23649 & 0.42970 & 2.49327 & 1.02723 & 0.81059 \\
\hline 39 & 2.21476 & 1.22286 & 0.42597 & 2.55644 & 1.10891 & 0.79613 \\
\hline 40 & 2.22241 & 1.20969 & 0.42292 & 2.60876 & 1.18369 & 0.78246 \\
\hline 41 & 2.22647 & 1.19701 & 0.42057 & 2.65051 & 1.25153 & 0.76960 \\
\hline 42 & 2.22704 & 1.18485 & 0.41894 & 2.68204 & 1.31244 & 0.75758 \\
\hline 43 & 2.22426 & 1.17323 & 0.41802 & 2.70379 & 1.36651 & 0.74643 \\
\hline 44 & 2.21827 & 1.16216 & 0.41782 & 2.71626 & 1.41389 & 0.73614 \\
\hline 45 & 2.20925 & 1.15166 & 0.41834 & 2.72001 & 1.45478 & 0.72673 \\
\hline 46 & 2.19739 & 1.14173 & 0.41958 & 2.71563 & 1.48942 & 0.71818 \\
\hline 47 & 2.18288 & 1.13236 & 0.42152 & 2.70373 & 1.51809 & 0.71049 \\
\hline 48 & 2.16591 & 1.12354 & 0.42416 & 2.68494 & 1.54110 & 0.70363 \\
\hline 49 & 2.14671 & 1.11528 & 0.42747 & 2.65990 & 1.55876 & 0.69759 \\
\hline 50 & 2.12546 & 1.10754 & 0.43145 & 2.62924 & 1.57143 & 0.69234 \\
\hline 51 & 2.10238 & 1.10032 & 0.43607 & 2.59356 & 1.57944 & 0.68785 \\
\hline 52 & 2.07766 & 1.09360 & 0.44132 & 2.55346 & 1.58315 & 0.68408 \\
\hline 53 & 2.05150 & 1.08735 & 0.44718 & 2.50950 & 1.58291 & 0.68101 \\
\hline 54 & 2.02406 & 1.08156 & 0.45363 & 2.46224 & 1.57905 & 0.67861 \\
\hline 55 & 1.99553 & 1.07620 & 0.46065 & 2.41217 & 1.57192 & 0.67683 \\
\hline 56 & 1.96607 & 1.07125 & 0.46823 & 2.35977 & 1.56182 & 0.67564 \\
\hline 57 & 1.93582 & 1.06668 & 0.47635 & 2.30547 & 1.54907 & 0.67501 \\
\hline 58 & 1.90494 & 1.06248 & 0.48499 & 2.24968 & 1.53395 & 0.67491 \\
\hline 59 & 1.87355 & 1.05861 & 0.49415 & 2.19277 & 1.51674 & 0.67530 \\
\hline 60 & 1.84176 & 1.05506 & 0.50380 & 2.13508 & 1.49769 & 0.67615 \\
\hline 61 & 1.80970 & 1.05181 & 0.51394 & 2.07690 & 1.47704 & 0.67744 \\
\hline
\end{tabular}


Appendix A1. Male Mortality Rates by Race/Ethnicity and Education Relative to the Average (cont.)

\begin{tabular}{|c|c|c|c|c|c|c|}
\hline \multirow[b]{3}{*}{ Age } & \multicolumn{6}{|c|}{ Male cohorts } \\
\hline & \multicolumn{3}{|c|}{ White } & \multicolumn{2}{|c|}{ Black } & \multirow[b]{2}{*}{ Hispanic } \\
\hline & $\begin{array}{c}\text { Less than } \\
\text { high school }\end{array}$ & $\begin{array}{l}\text { HS/some } \\
\text { college }\end{array}$ & $\begin{array}{l}\text { College } \\
\text { grads }\end{array}$ & $\begin{array}{c}\text { Less than } \\
\text { high school }\end{array}$ & $\begin{array}{l}\text { High school } \\
\text { or more }\end{array}$ & \\
\hline 62 & 1.77746 & 1.04883 & 0.52456 & 2.01851 & 1.45502 & 0.67913 \\
\hline 63 & 1.74513 & 1.04611 & 0.53564 & 1.96015 & 1.43183 & 0.68121 \\
\hline 64 & 1.71279 & 1.04362 & 0.54718 & 1.90203 & 1.40765 & 0.68363 \\
\hline 65 & 1.68051 & 1.04135 & 0.55917 & 1.84435 & 1.38266 & 0.68639 \\
\hline 66 & 1.64837 & 1.03928 & 0.57160 & 1.78727 & 1.35702 & 0.68947 \\
\hline 67 & 1.61641 & 1.03740 & 0.58448 & 1.73094 & 1.33087 & 0.69283 \\
\hline 68 & 1.58469 & 1.03569 & 0.59780 & 1.67547 & 1.30434 & 0.69646 \\
\hline 69 & 1.55326 & 1.03414 & 0.61155 & 1.62097 & 1.27754 & 0.70035 \\
\hline 70 & 1.52216 & 1.03273 & 0.62573 & 1.56754 & 1.25059 & 0.70447 \\
\hline 71 & 1.49142 & 1.03145 & 0.64035 & 1.51525 & 1.22358 & 0.70883 \\
\hline 72 & 1.46107 & 1.03030 & 0.65540 & 1.46416 & 1.19659 & 0.71339 \\
\hline 73 & 1.43115 & 1.02925 & 0.67088 & 1.41432 & 1.16970 & 0.71816 \\
\hline 74 & 1.40167 & 1.02831 & 0.68679 & 1.36576 & 1.14299 & 0.72311 \\
\hline 75 & 1.37265 & 1.02745 & 0.70313 & 1.31853 & 1.11650 & 0.72825 \\
\hline 76 & 1.34412 & 1.02669 & 0.71991 & 1.27263 & 1.09030 & 0.73356 \\
\hline 77 & 1.31609 & 1.02599 & 0.73712 & 1.22810 & 1.06443 & 0.73904 \\
\hline 78 & 1.28858 & 1.02537 & 0.75476 & 1.18492 & 1.03894 & 0.74467 \\
\hline 79 & 1.26159 & 1.02480 & 0.77284 & 1.14311 & 1.01386 & 0.75045 \\
\hline 80 & 1.23514 & 1.02430 & 0.79134 & 1.10267 & 0.98923 & 0.75638 \\
\hline 81 & 1.20924 & 1.02384 & 0.81026 & 1.06359 & 0.96508 & 0.76245 \\
\hline 82 & 1.18389 & 1.02343 & 0.82960 & 1.02586 & 0.94142 & 0.76866 \\
\hline 83 & 1.15911 & 1.02305 & 0.84935 & 0.98946 & 0.91830 & 0.77500 \\
\hline 84 & 1.13490 & 1.02271 & 0.86950 & 0.95440 & 0.89572 & 0.78148 \\
\hline 85 & 1.11126 & 1.02240 & 0.89002 & 0.92064 & 0.87370 & 0.78807 \\
\hline 86 & 1.08822 & 1.02212 & 0.91091 & 0.88817 & 0.85227 & 0.79479 \\
\hline 87 & 1.06577 & 1.02186 & 0.93213 & 0.85698 & 0.83144 & 0.80164 \\
\hline 88 & 1.04392 & 1.02162 & 0.95365 & 0.82704 & 0.81121 & 0.80859 \\
\hline 89 & 1.02269 & 1.02139 & 0.97543 & 0.79834 & 0.79161 & 0.81567 \\
\hline 90 & 1.00208 & 1.02118 & 0.99743 & 0.77086 & 0.77265 & 0.82285 \\
\hline 91 & 0.98209 & 1.02097 & 1.01958 & 0.74457 & 0.75434 & 0.83014 \\
\hline 92 & 0.96275 & 1.02077 & 1.04182 & 0.71947 & 0.73668 & 0.83753 \\
\hline 93 & 0.94406 & 1.02057 & 1.06405 & 0.69552 & 0.71970 & 0.84501 \\
\hline 94 & 0.92605 & 1.02037 & 1.08620 & 0.67272 & 0.70340 & 0.85259 \\
\hline 95 & 0.90871 & 1.02016 & 1.10813 & 0.65104 & 0.68781 & 0.86025 \\
\hline 96 & 0.89207 & 1.01994 & 1.12972 & 0.63048 & 0.67292 & 0.86799 \\
\hline 97 & 0.87615 & 1.01971 & 1.15082 & 0.61101 & 0.65876 & 0.87579 \\
\hline 98 & 0.86097 & 1.01947 & 1.17126 & 0.59263 & 0.64534 & 0.88364 \\
\hline 99 & 0.84654 & 1.01922 & 1.19084 & 0.57533 & 0.63268 & 0.89154 \\
\hline 100 & 0.83291 & 1.01894 & 1.20935 & 0.55910 & 0.62080 & 0.89945 \\
\hline
\end{tabular}

Source: Authors calculations based on restricted NLMS data provided by the U.S. Census. 
Appendix A2. Female Mortality Rates by Race/Ethnicity and Education Relative to the Average

\begin{tabular}{|c|c|c|c|c|c|c|}
\hline \multirow[b]{2}{*}{ Age } & \multicolumn{3}{|c|}{ White } & \multicolumn{2}{|c|}{ Black } & \multirow[b]{2}{*}{ Hispanic } \\
\hline & $\begin{array}{c}\text { Less than } \\
\text { high school }\end{array}$ & $\begin{array}{c}\text { HS/some } \\
\text { college }\end{array}$ & $\begin{array}{c}\text { College } \\
\text { grads }\end{array}$ & $\begin{array}{c}\text { Less than } \\
\text { high school }\end{array}$ & $\begin{array}{l}\text { High school } \\
\text { or more }\end{array}$ & \\
\hline 25 & 2.04546 & 1.14403 & 0.95417 & 3.54499 & 1.17105 & 0.45752 \\
\hline 26 & 2.06783 & 1.14015 & 0.94121 & 3.55590 & 1.18417 & 0.46079 \\
\hline 27 & 2.09050 & 1.13600 & 0.92739 & 3.56549 & 1.19772 & 0.46432 \\
\hline 28 & 2.11332 & 1.13159 & 0.91270 & 3.57352 & 1.21167 & 0.46812 \\
\hline 29 & 2.13613 & 1.12690 & 0.89715 & 3.57972 & 1.22594 & 0.47219 \\
\hline 30 & 2.15875 & 1.12195 & 0.88076 & 3.58382 & 1.24045 & 0.47655 \\
\hline 31 & 2.18098 & 1.11674 & 0.86354 & 3.58552 & 1.25513 & 0.48119 \\
\hline 32 & 2.20261 & 1.11128 & 0.84555 & 3.58455 & 1.26988 & 0.48612 \\
\hline 33 & 2.22340 & 1.10558 & 0.82684 & 3.58064 & 1.28458 & 0.49132 \\
\hline 34 & 2.24311 & 1.09966 & 0.80749 & 3.57351 & 1.29911 & 0.49679 \\
\hline 35 & 2.26149 & 1.09355 & 0.78757 & 3.56293 & 1.31336 & 0.50253 \\
\hline 36 & 2.27831 & 1.08725 & 0.76720 & 3.54867 & 1.32719 & 0.50851 \\
\hline 37 & 2.29331 & 1.08082 & 0.74649 & 3.53055 & 1.34046 & 0.51471 \\
\hline 38 & 2.30626 & 1.07427 & 0.72557 & 3.50842 & 1.35303 & 0.52111 \\
\hline 39 & 2.31694 & 1.06765 & 0.70458 & 3.48219 & 1.36478 & 0.52769 \\
\hline 40 & 2.32516 & 1.06099 & 0.68367 & 3.45180 & 1.37557 & 0.53442 \\
\hline 41 & 2.33074 & 1.05433 & 0.66298 & 3.41727 & 1.38529 & 0.54126 \\
\hline 42 & 2.33355 & 1.04772 & 0.64268 & 3.37864 & 1.39382 & 0.54817 \\
\hline 43 & 2.33349 & 1.04120 & 0.62292 & 3.33604 & 1.40107 & 0.55513 \\
\hline 44 & 2.33048 & 1.03479 & 0.60384 & 3.28963 & 1.40696 & 0.56210 \\
\hline 45 & 2.32450 & 1.02855 & 0.58559 & 3.23963 & 1.41143 & 0.56905 \\
\hline 46 & 2.31557 & 1.02251 & 0.56831 & 3.18628 & 1.41444 & 0.57593 \\
\hline 47 & 2.30372 & 1.01669 & 0.55211 & 3.12989 & 1.41597 & 0.58273 \\
\hline 48 & 2.28905 & 1.01112 & 0.53709 & 3.07077 & 1.41601 & 0.58940 \\
\hline 49 & 2.27167 & 1.00583 & 0.52336 & 3.00928 & 1.41458 & 0.59593 \\
\hline 50 & 2.25171 & 1.00084 & 0.51098 & 2.94575 & 1.41170 & 0.60229 \\
\hline 51 & 2.22935 & 0.99616 & 0.50002 & 2.88056 & 1.40743 & 0.60845 \\
\hline 52 & 2.20477 & 0.99180 & 0.49051 & 2.81405 & 1.40182 & 0.61442 \\
\hline 53 & 2.17816 & 0.98776 & 0.48248 & 2.74658 & 1.39495 & 0.62017 \\
\hline 54 & 2.14972 & 0.98405 & 0.47596 & 2.67848 & 1.38689 & 0.62569 \\
\hline 55 & 2.11966 & 0.98066 & 0.47094 & 2.61006 & 1.37772 & 0.63098 \\
\hline 56 & 2.08819 & 0.97760 & 0.46741 & 2.54160 & 1.36754 & 0.63604 \\
\hline 57 & 2.05550 & 0.97484 & 0.46535 & 2.47338 & 1.35644 & 0.64087 \\
\hline 58 & 2.02179 & 0.97239 & 0.46475 & 2.40562 & 1.34450 & 0.64547 \\
\hline 59 & 1.98725 & 0.97023 & 0.46557 & 2.33855 & 1.33182 & 0.64985 \\
\hline 60 & 1.95206 & 0.96834 & 0.46777 & 2.27235 & 1.31848 & 0.65402 \\
\hline 61 & 1.91636 & 0.96672 & 0.47133 & 2.20717 & 1.30458 & 0.65797 \\
\hline
\end{tabular}


Appendix A2. Female Mortality Rates by Race/Ethnicity and Education Relative to the Average

\begin{tabular}{|c|c|c|c|c|c|c|}
\hline \multirow[b]{2}{*}{ Age } & \multicolumn{3}{|c|}{ White } & \multicolumn{2}{|c|}{ Black } & \multirow[b]{2}{*}{ Hispanic } \\
\hline & $\begin{array}{c}\text { Less than } \\
\text { high school }\end{array}$ & $\begin{array}{l}\text { HS/some } \\
\text { college }\end{array}$ & $\begin{array}{l}\text { College } \\
\text { grads }\end{array}$ & $\begin{array}{c}\text { Less than } \\
\text { high school }\end{array}$ & $\begin{array}{l}\text { High school } \\
\text { or more }\end{array}$ & \\
\hline 62 & 1.88032 & 0.96535 & 0.47620 & 2.14315 & 1.29017 & 0.66173 \\
\hline 63 & 1.84407 & 0.96421 & 0.48234 & 2.08039 & 1.27536 & 0.66531 \\
\hline 64 & 1.80774 & 0.96328 & 0.48972 & 2.01899 & 1.26019 & 0.66870 \\
\hline 65 & 1.77143 & 0.96256 & 0.49830 & 1.95902 & 1.24475 & 0.67193 \\
\hline 66 & 1.73525 & 0.96203 & 0.50805 & 1.90052 & 1.22908 & 0.67501 \\
\hline 67 & 1.69927 & 0.96168 & 0.51893 & 1.84354 & 1.21325 & 0.67795 \\
\hline 68 & 1.66358 & 0.96148 & 0.53091 & 1.78809 & 1.19729 & 0.68075 \\
\hline 69 & 1.62825 & 0.96144 & 0.54397 & 1.73420 & 1.18127 & 0.68344 \\
\hline 70 & 1.59332 & 0.96153 & 0.55809 & 1.68186 & 1.16522 & 0.68602 \\
\hline 71 & 1.55886 & 0.96175 & 0.57324 & 1.63107 & 1.14917 & 0.68850 \\
\hline 72 & 1.52489 & 0.96208 & 0.58942 & 1.58182 & 1.13315 & 0.69089 \\
\hline 73 & 1.49146 & 0.96252 & 0.60660 & 1.53408 & 1.11721 & 0.69321 \\
\hline 74 & 1.45859 & 0.96305 & 0.62477 & 1.48783 & 1.10136 & 0.69546 \\
\hline 75 & 1.42630 & 0.96367 & 0.64393 & 1.44305 & 1.08562 & 0.69766 \\
\hline 76 & 1.39463 & 0.96437 & 0.66408 & 1.39971 & 1.07003 & 0.69980 \\
\hline 77 & 1.36357 & 0.96514 & 0.68519 & 1.35778 & 1.05458 & 0.70191 \\
\hline 78 & 1.33315 & 0.96598 & 0.70729 & 1.31723 & 1.03932 & 0.70399 \\
\hline 79 & 1.30338 & 0.96688 & 0.73035 & 1.27803 & 1.02424 & 0.70605 \\
\hline 80 & 1.27425 & 0.96783 & 0.75438 & 1.24014 & 1.00936 & 0.70809 \\
\hline 81 & 1.24579 & 0.96884 & 0.77938 & 1.20354 & 0.99470 & 0.71013 \\
\hline 82 & 1.21799 & 0.96989 & 0.80534 & 1.16818 & 0.98027 & 0.71218 \\
\hline 83 & 1.19085 & 0.97098 & 0.83226 & 1.13406 & 0.96608 & 0.71424 \\
\hline 84 & 1.16438 & 0.97210 & 0.86011 & 1.10112 & 0.95214 & 0.71633 \\
\hline 85 & 1.13859 & 0.97326 & 0.88889 & 1.06936 & 0.93847 & 0.71844 \\
\hline 86 & 1.11347 & 0.97446 & 0.91857 & 1.03874 & 0.92507 & 0.72060 \\
\hline 87 & 1.08904 & 0.97567 & 0.94912 & 1.00924 & 0.91197 & 0.72282 \\
\hline 88 & 1.06529 & 0.97691 & 0.98049 & 0.98084 & 0.89916 & 0.72509 \\
\hline 89 & 1.04222 & 0.97818 & 1.01262 & 0.95353 & 0.88667 & 0.72744 \\
\hline 90 & 1.01986 & 0.97946 & 1.04543 & 0.92728 & 0.87450 & 0.72988 \\
\hline 91 & 0.99819 & 0.98075 & 1.07882 & 0.90208 & 0.86268 & 0.73242 \\
\hline 92 & 0.97724 & 0.98206 & 1.11266 & 0.87791 & 0.85122 & 0.73507 \\
\hline 93 & 0.95702 & 0.98338 & 1.14680 & 0.85478 & 0.84014 & 0.73784 \\
\hline 94 & 0.93752 & 0.98471 & 1.18104 & 0.83268 & 0.82947 & 0.74076 \\
\hline 95 & 0.91878 & 0.98603 & 1.21516 & 0.81159 & 0.81921 & 0.74384 \\
\hline 96 & 0.90081 & 0.98736 & 1.24886 & 0.79153 & 0.80941 & 0.74710 \\
\hline 97 & 0.88362 & 0.98869 & 1.28183 & 0.77249 & 0.80007 & 0.75055 \\
\hline 98 & 0.86725 & 0.99000 & 1.31367 & 0.75448 & 0.79125 & 0.75422 \\
\hline 99 & 0.85172 & 0.99131 & 1.34394 & 0.73751 & 0.78296 & 0.75812 \\
\hline 100 & 0.99259 & 1.37214 & 0.72160 & 0.77524 & 0.76229 & 0.76229 \\
\hline
\end{tabular}

Source: Authors calculations based on restricted NLMS data provided by the U.S. Census. 
Appendix B1. Male Mortality Rates by Race/Ethnicity and Education, 2004-2011

\begin{tabular}{|c|c|c|c|c|c|c|}
\hline \multirow[b]{2}{*}{ Age } & \multicolumn{3}{|c|}{ White } & \multicolumn{2}{|c|}{ Black } & \multirow[b]{2}{*}{ Hispanic } \\
\hline & $\begin{array}{c}\text { Less than } \\
\text { high school }\end{array}$ & $\begin{array}{l}\text { HS/some } \\
\text { college }\end{array}$ & $\begin{array}{l}\text { College } \\
\text { grads }\end{array}$ & $\begin{array}{c}\text { Less than } \\
\text { high school }\end{array}$ & $\begin{array}{l}\text { High school } \\
\text { or more }\end{array}$ & \\
\hline 25 & 0.00357 & 0.00290 & 0.00106 & 0.00156 & 0.00000 & 0.00211 \\
\hline 26 & 0.00332 & 0.00261 & 0.00094 & 0.00174 & 0.00000 & 0.00188 \\
\hline 27 & 0.00347 & 0.00262 & 0.00094 & 0.00209 & 0.00000 & 0.00187 \\
\hline 28 & 0.00344 & 0.00251 & 0.00090 & 0.00233 & 0.00000 & 0.00178 \\
\hline 29 & 0.00365 & 0.00258 & 0.00092 & 0.00272 & 0.00005 & 0.00181 \\
\hline 30 & 0.00375 & 0.00256 & 0.00091 & 0.00303 & 0.00030 & 0.00179 \\
\hline 31 & 0.00374 & 0.00248 & 0.00087 & 0.00323 & 0.00052 & 0.00172 \\
\hline 32 & 0.00383 & 0.00246 & 0.00086 & 0.00351 & 0.00075 & 0.00169 \\
\hline 33 & 0.00391 & 0.00245 & 0.00086 & 0.00376 & 0.00098 & 0.00167 \\
\hline 34 & 0.00418 & 0.00255 & 0.00089 & 0.00420 & 0.00125 & 0.00172 \\
\hline 35 & 0.00460 & 0.00274 & 0.00095 & 0.00479 & 0.00159 & 0.00184 \\
\hline 36 & 0.00516 & 0.00301 & 0.00105 & 0.00555 & 0.00201 & 0.00200 \\
\hline 37 & 0.00573 & 0.00328 & 0.00114 & 0.00634 & 0.00246 & 0.00216 \\
\hline 38 & 0.00621 & 0.00349 & 0.00121 & 0.00703 & 0.00290 & 0.00229 \\
\hline 39 & 0.00660 & 0.00364 & 0.00127 & 0.00762 & 0.00330 & 0.00237 \\
\hline 40 & 0.00687 & 0.00374 & 0.00131 & 0.00806 & 0.00366 & 0.00242 \\
\hline 41 & 0.00719 & 0.00387 & 0.00136 & 0.00856 & 0.00404 & 0.00249 \\
\hline 42 & 0.00800 & 0.00425 & 0.00150 & 0.00963 & 0.00471 & 0.00272 \\
\hline 43 & 0.00867 & 0.00458 & 0.00163 & 0.01054 & 0.00533 & 0.00291 \\
\hline 44 & 0.00918 & 0.00481 & 0.00173 & 0.01125 & 0.00585 & 0.00305 \\
\hline 45 & 0.00963 & 0.00502 & 0.00182 & 0.01186 & 0.00634 & 0.00317 \\
\hline 46 & 0.00958 & 0.00498 & 0.00183 & 0.01184 & 0.00649 & 0.00313 \\
\hline 47 & 0.00987 & 0.00512 & 0.00191 & 0.01222 & 0.00686 & 0.00321 \\
\hline 48 & 0.01031 & 0.00535 & 0.00202 & 0.01278 & 0.00734 & 0.00335 \\
\hline 49 & 0.01095 & 0.00569 & 0.00218 & 0.01357 & 0.00795 & 0.00356 \\
\hline 50 & 0.01158 & 0.00604 & 0.00235 & 0.01433 & 0.00856 & 0.00377 \\
\hline 51 & 0.01255 & 0.00657 & 0.00260 & 0.01548 & 0.00943 & 0.00411 \\
\hline 52 & 0.01255 & 0.00661 & 0.00267 & 0.01542 & 0.00956 & 0.00413 \\
\hline 53 & 0.01323 & 0.00701 & 0.00288 & 0.01619 & 0.01021 & 0.00439 \\
\hline 54 & 0.01399 & 0.00747 & 0.00313 & 0.01701 & 0.01091 & 0.00469 \\
\hline 55 & 0.01483 & 0.00800 & 0.00342 & 0.01792 & 0.01168 & 0.00503 \\
\hline 56 & 0.01573 & 0.00857 & 0.00375 & 0.01888 & 0.01249 & 0.00541 \\
\hline 57 & 0.01669 & 0.00919 & 0.00411 & 0.01987 & 0.01335 & 0.00582 \\
\hline 58 & 0.01770 & 0.00987 & 0.00451 & 0.02090 & 0.01425 & 0.00627 \\
\hline 59 & 0.01879 & 0.01062 & 0.00496 & 0.02199 & 0.01521 & 0.00677 \\
\hline 60 & 0.02000 & 0.01146 & 0.00547 & 0.02319 & 0.01626 & 0.00734 \\
\hline 61 & 0.02134 & 0.01240 & 0.00606 & 0.02449 & 0.01741 & 0.00799 \\
\hline
\end{tabular}


Appendix B1. Male Mortality Rates by Race/Ethnicity and Education, 2004-2011 (cont.)

\begin{tabular}{|c|c|c|c|c|c|c|}
\hline \multirow[b]{2}{*}{ Age } & \multicolumn{3}{|c|}{ White } & \multicolumn{2}{|c|}{ Black } & \multirow[b]{2}{*}{ Hispanic } \\
\hline & $\begin{array}{c}\text { Less than } \\
\text { high school }\end{array}$ & $\begin{array}{l}\text { HS/some } \\
\text { college }\end{array}$ & $\begin{array}{l}\text { College } \\
\text { grads }\end{array}$ & $\begin{array}{c}\text { Less than } \\
\text { high school }\end{array}$ & $\begin{array}{l}\text { High school } \\
\text { or more }\end{array}$ & \\
\hline 62 & 0.02280 & 0.01346 & 0.00673 & 0.02590 & 0.01867 & 0.00871 \\
\hline 63 & 0.02440 & 0.01462 & 0.00749 & 0.02740 & 0.02002 & 0.00952 \\
\hline 64 & 0.02615 & 0.01594 & 0.00836 & 0.02904 & 0.02149 & 0.01044 \\
\hline 65 & 0.02805 & 0.01738 & 0.00933 & 0.03078 & 0.02308 & 0.01146 \\
\hline 66 & 0.03008 & 0.01897 & 0.01043 & 0.03262 & 0.02477 & 0.01258 \\
\hline 67 & 0.03215 & 0.02063 & 0.01163 & 0.03443 & 0.02647 & 0.01378 \\
\hline 68 & 0.03423 & 0.02237 & 0.01291 & 0.03619 & 0.02817 & 0.01504 \\
\hline 69 & 0.03636 & 0.02421 & 0.01432 & 0.03795 & 0.02991 & 0.01640 \\
\hline 70 & 0.03878 & 0.02631 & 0.01594 & 0.03994 & 0.03187 & 0.01795 \\
\hline 71 & 0.04140 & 0.02863 & 0.01778 & 0.04206 & 0.03397 & 0.01968 \\
\hline 72 & 0.04396 & 0.03100 & 0.01972 & 0.04406 & 0.03601 & 0.02147 \\
\hline 73 & 0.04638 & 0.03336 & 0.02174 & 0.04584 & 0.03791 & 0.02328 \\
\hline 74 & 0.04886 & 0.03585 & 0.02394 & 0.04761 & 0.03984 & 0.02521 \\
\hline 75 & 0.05180 & 0.03878 & 0.02654 & 0.04976 & 0.04214 & 0.02748 \\
\hline 76 & 0.05526 & 0.04221 & 0.02960 & 0.05232 & 0.04482 & 0.03016 \\
\hline 77 & 0.05897 & 0.04597 & 0.03303 & 0.05503 & 0.04770 & 0.03312 \\
\hline 78 & 0.06291 & 0.05006 & 0.03685 & 0.05785 & 0.05072 & 0.03635 \\
\hline 79 & 0.06723 & 0.05461 & 0.04118 & 0.06092 & 0.05403 & 0.03999 \\
\hline 80 & 0.07197 & 0.05969 & 0.04611 & 0.06425 & 0.05764 & 0.04407 \\
\hline 81 & 0.07746 & 0.06559 & 0.05191 & 0.06813 & 0.06182 & 0.04884 \\
\hline 82 & 0.08406 & 0.07266 & 0.05890 & 0.07284 & 0.06684 & 0.05458 \\
\hline 83 & 0.09193 & 0.08114 & 0.06736 & 0.07847 & 0.07283 & 0.06147 \\
\hline 84 & 0.10088 & 0.09091 & 0.07729 & 0.08484 & 0.07962 & 0.06947 \\
\hline 85 & 0.11052 & 0.10168 & 0.08851 & 0.09156 & 0.08689 & 0.07837 \\
\hline 86 & 0.12053 & 0.11321 & 0.10089 & 0.09837 & 0.09440 & 0.08803 \\
\hline 87 & 0.13072 & 0.12533 & 0.11433 & 0.10511 & 0.10198 & 0.09832 \\
\hline 88 & 0.14099 & 0.13798 & 0.12880 & 0.11170 & 0.10956 & 0.10921 \\
\hline 89 & 0.15139 & 0.15120 & 0.14439 & 0.11818 & 0.11718 & 0.12074 \\
\hline 90 & 0.16199 & 0.16507 & 0.16123 & 0.12461 & 0.12490 & 0.13301 \\
\hline 91 & 0.17286 & 0.17970 & 0.17946 & 0.13105 & 0.13277 & 0.14611 \\
\hline 92 & 0.18410 & 0.19519 & 0.19922 & 0.13758 & 0.14087 & 0.16015 \\
\hline 93 & 0.19577 & 0.21164 & 0.22065 & 0.14423 & 0.14924 & 0.17523 \\
\hline 94 & 0.20793 & 0.22911 & 0.24389 & 0.15105 & 0.15794 & 0.19144 \\
\hline 95 & 0.21938 & 0.24629 & 0.26752 & 0.15717 & 0.16605 & 0.20768 \\
\hline 96 & 0.22989 & 0.26284 & 0.29113 & 0.16247 & 0.17341 & 0.22368 \\
\hline 97 & 0.23926 & 0.27846 & 0.31427 & 0.16686 & 0.17989 & 0.23916 \\
\hline 98 & 0.24732 & 0.29285 & 0.33646 & 0.17024 & 0.18538 & 0.25384 \\
\hline 99 & 0.25390 & 0.30569 & 0.35717 & 0.17256 & 0.18976 & 0.26740 \\
\hline 100 & 0.26084 & 0.31910 & 0.37873 & 0.17509 & 0.19442 & 0.28168 \\
\hline
\end{tabular}

Sources: Authors calculations based on restricted NLMS data provided by the U.S. Census and 1950 Birth Cohort Mortality Rates from the Social Security Administration. 
Appendix B2. Female Mortality Rates by Race/Ethnicity and Education, 2004-2011

\begin{tabular}{|c|c|c|c|c|c|c|}
\hline \multirow[b]{2}{*}{ Age } & \multicolumn{3}{|c|}{ White } & \multicolumn{2}{|c|}{ Black } & \multirow[b]{2}{*}{ Hispanic } \\
\hline & $\begin{array}{c}\text { Less than } \\
\text { high school }\end{array}$ & $\begin{array}{l}\text { HS/some } \\
\text { college }\end{array}$ & $\begin{array}{c}\text { College } \\
\text { grads }\end{array}$ & $\begin{array}{c}\text { Less than } \\
\text { high school }\end{array}$ & $\begin{array}{c}\text { High school } \\
\text { or more }\end{array}$ & \\
\hline 25 & 0.00141 & 0.00079 & 0.00066 & 0.00245 & 0.00081 & 0.00032 \\
\hline 26 & 0.00141 & 0.00078 & 0.00064 & 0.00242 & 0.00081 & 0.00031 \\
\hline 27 & 0.00144 & 0.00078 & 0.00064 & 0.00246 & 0.00083 & 0.00032 \\
\hline 28 & 0.00152 & 0.00081 & 0.00066 & 0.00257 & 0.00087 & 0.00034 \\
\hline 29 & 0.00152 & 0.00080 & 0.00064 & 0.00254 & 0.00087 & 0.00034 \\
\hline 30 & 0.00162 & 0.00084 & 0.00066 & 0.00269 & 0.00093 & 0.00036 \\
\hline 31 & 0.00166 & 0.00085 & 0.00066 & 0.00272 & 0.00095 & 0.00037 \\
\hline 32 & 0.00172 & 0.00087 & 0.00066 & 0.00280 & 0.00099 & 0.00038 \\
\hline 33 & 0.00180 & 0.00090 & 0.00067 & 0.00290 & 0.00104 & 0.00040 \\
\hline 34 & 0.00200 & 0.00098 & 0.00072 & 0.00318 & 0.00116 & 0.00044 \\
\hline 35 & 0.00215 & 0.00104 & 0.00075 & 0.00338 & 0.00125 & 0.00048 \\
\hline 36 & 0.00230 & 0.00110 & 0.00077 & 0.00358 & 0.00134 & 0.00051 \\
\hline 37 & 0.00264 & 0.00124 & 0.00086 & 0.00406 & 0.00154 & 0.00059 \\
\hline 38 & 0.00288 & 0.00134 & 0.00091 & 0.00439 & 0.00169 & 0.00065 \\
\hline 39 & 0.00304 & 0.00140 & 0.00092 & 0.00456 & 0.00179 & 0.00069 \\
\hline 40 & 0.00321 & 0.00146 & 0.00094 & 0.00476 & 0.00190 & 0.00074 \\
\hline 41 & 0.00345 & 0.00156 & 0.00098 & 0.00506 & 0.00205 & 0.00080 \\
\hline 42 & 0.00387 & 0.00174 & 0.00107 & 0.00561 & 0.00231 & 0.00091 \\
\hline 43 & 0.00427 & 0.00191 & 0.00114 & 0.00610 & 0.00256 & 0.00102 \\
\hline 44 & 0.00466 & 0.00207 & 0.00121 & 0.00658 & 0.00281 & 0.00112 \\
\hline 45 & 0.00504 & 0.00223 & 0.00127 & 0.00703 & 0.00306 & 0.00123 \\
\hline 46 & 0.00530 & 0.00234 & 0.00130 & 0.00730 & 0.00324 & 0.00132 \\
\hline 47 & 0.00569 & 0.00251 & 0.00136 & 0.00773 & 0.00350 & 0.00144 \\
\hline 48 & 0.00602 & 0.00266 & 0.00141 & 0.00808 & 0.00372 & 0.00155 \\
\hline 49 & 0.00659 & 0.00292 & 0.00152 & 0.00873 & 0.00410 & 0.00173 \\
\hline 50 & 0.00709 & 0.00315 & 0.00161 & 0.00928 & 0.00445 & 0.00190 \\
\hline 51 & 0.00780 & 0.00349 & 0.00175 & 0.01008 & 0.00493 & 0.00213 \\
\hline 52 & 0.00803 & 0.00361 & 0.00179 & 0.01024 & 0.00510 & 0.00224 \\
\hline 53 & 0.00860 & 0.00390 & 0.00191 & 0.01085 & 0.00551 & 0.00245 \\
\hline 54 & 0.00924 & 0.00423 & 0.00205 & 0.01152 & 0.00596 & 0.00269 \\
\hline 55 & 0.00996 & 0.00461 & 0.00221 & 0.01227 & 0.00648 & 0.00297 \\
\hline 56 & 0.01073 & 0.00502 & 0.00240 & 0.01306 & 0.00703 & 0.00327 \\
\hline 57 & 0.01157 & 0.00549 & 0.00262 & 0.01393 & 0.00764 & 0.00361 \\
\hline 58 & 0.01243 & 0.00598 & 0.00286 & 0.01479 & 0.00827 & 0.00397 \\
\hline 59 & 0.01335 & 0.00652 & 0.00313 & 0.01572 & 0.00895 & 0.00437 \\
\hline 60 & 0.01433 & 0.00711 & 0.00343 & 0.01668 & 0.00968 & 0.00480 \\
\hline 61 & 0.01541 & 0.00777 & 0.00379 & 0.01775 & 0.01049 & 0.00529 \\
\hline
\end{tabular}


Appendix B2. Female Mortality Rates by Race/Ethnicity and Education, 2004-2011 (cont.)

\begin{tabular}{|c|c|c|c|c|c|c|}
\hline \multirow[b]{2}{*}{ Age } & \multicolumn{3}{|c|}{ White } & \multicolumn{2}{|c|}{ Black } & \multirow[b]{2}{*}{ Hispanic } \\
\hline & $\begin{array}{c}\text { Less than } \\
\text { high school }\end{array}$ & $\begin{array}{l}\text { HS/some } \\
\text { college }\end{array}$ & $\begin{array}{l}\text { College } \\
\text { grads }\end{array}$ & $\begin{array}{c}\text { Less than } \\
\text { high school }\end{array}$ & $\begin{array}{l}\text { High school } \\
\text { or more }\end{array}$ & \\
\hline 62 & 0.01655 & 0.00850 & 0.00419 & 0.01886 & 0.01135 & 0.00582 \\
\hline 63 & 0.01778 & 0.00929 & 0.00465 & 0.02005 & 0.01229 & 0.00641 \\
\hline 64 & 0.01907 & 0.01016 & 0.00517 & 0.02130 & 0.01330 & 0.00705 \\
\hline 65 & 0.02050 & 0.01114 & 0.00577 & 0.02267 & 0.01440 & 0.00777 \\
\hline 66 & 0.02200 & 0.01220 & 0.00644 & 0.02410 & 0.01558 & 0.00856 \\
\hline 67 & 0.02352 & 0.01331 & 0.00718 & 0.02551 & 0.01679 & 0.00938 \\
\hline 68 & 0.02504 & 0.01447 & 0.00799 & 0.02691 & 0.01802 & 0.01025 \\
\hline 69 & 0.02659 & 0.01570 & 0.00888 & 0.02832 & 0.01929 & 0.01116 \\
\hline 70 & 0.02835 & 0.01711 & 0.00993 & 0.02992 & 0.02073 & 0.01220 \\
\hline 71 & 0.03026 & 0.01867 & 0.01113 & 0.03166 & 0.02231 & 0.01336 \\
\hline 72 & 0.03216 & 0.02029 & 0.01243 & 0.03336 & 0.02390 & 0.01457 \\
\hline 73 & 0.03401 & 0.02195 & 0.01383 & 0.03498 & 0.02547 & 0.01581 \\
\hline 74 & 0.03591 & 0.02371 & 0.01538 & 0.03663 & 0.02712 & 0.01712 \\
\hline 75 & 0.03820 & 0.02581 & 0.01724 & 0.03864 & 0.02907 & 0.01868 \\
\hline 76 & 0.04088 & 0.02827 & 0.01946 & 0.04103 & 0.03136 & 0.02051 \\
\hline 77 & 0.04366 & 0.03090 & 0.02194 & 0.04348 & 0.03377 & 0.02248 \\
\hline 78 & 0.04651 & 0.03370 & 0.02468 & 0.04596 & 0.03626 & 0.02456 \\
\hline 79 & 0.04958 & 0.03678 & 0.02778 & 0.04862 & 0.03896 & 0.02686 \\
\hline 80 & 0.05311 & 0.04034 & 0.03144 & 0.05169 & 0.04207 & 0.02951 \\
\hline 81 & 0.05729 & 0.04456 & 0.03584 & 0.05535 & 0.04575 & 0.03266 \\
\hline 82 & 0.06225 & 0.04957 & 0.04116 & 0.05971 & 0.05010 & 0.03640 \\
\hline 83 & 0.06809 & 0.05552 & 0.04759 & 0.06485 & 0.05524 & 0.04084 \\
\hline 84 & 0.07479 & 0.06244 & 0.05524 & 0.07073 & 0.06116 & 0.04601 \\
\hline 85 & 0.08222 & 0.07028 & 0.06419 & 0.07722 & 0.06777 & 0.05188 \\
\hline 86 & 0.09024 & 0.07897 & 0.07444 & 0.08418 & 0.07497 & 0.05840 \\
\hline 87 & 0.09873 & 0.08845 & 0.08605 & 0.09150 & 0.08268 & 0.06553 \\
\hline 88 & 0.10766 & 0.09873 & 0.09909 & 0.09912 & 0.09087 & 0.07328 \\
\hline 89 & 0.11700 & 0.10981 & 0.11368 & 0.10704 & 0.09954 & 0.08166 \\
\hline 90 & 0.12678 & 0.12176 & 0.12996 & 0.11527 & 0.10871 & 0.09073 \\
\hline 91 & 0.13702 & 0.13463 & 0.14809 & 0.12383 & 0.11842 & 0.10054 \\
\hline 92 & 0.14775 & 0.14848 & 0.16822 & 0.13273 & 0.12870 & 0.11113 \\
\hline 93 & 0.15899 & 0.16337 & 0.19052 & 0.14200 & 0.13957 & 0.12258 \\
\hline 94 & 0.17075 & 0.17934 & 0.21510 & 0.15166 & 0.15107 & 0.13492 \\
\hline 95 & 0.18205 & 0.19537 & 0.24077 & 0.16081 & 0.16232 & 0.14738 \\
\hline 96 & 0.19267 & 0.21118 & 0.26711 & 0.16929 & 0.17312 & 0.15979 \\
\hline 97 & 0.20240 & 0.22647 & 0.29362 & 0.17695 & 0.18326 & 0.17192 \\
\hline 98 & 0.21105 & 0.24092 & 0.31968 & 0.18360 & 0.19255 & 0.18354 \\
\hline 99 & 0.21843 & 0.25423 & 0.34467 & 0.18914 & 0.20080 & 0.19443 \\
\hline 100 & 0.26829 & 0.37088 & 0.19504 & 0.20954 & 0.20604 & 0.20604 \\
\hline
\end{tabular}

Sources: Authors calculations based on restricted NLMS data provided by the U.S. Census and 1950 Birth Cohort Mortality Rates from the Social Security Administration. 


\section{RECENT WORKING PAPERS FROM THE CENTER FOR RETIREMENT RESEARCH AT BOSTON COLLEGE}

Do Late-Career Wages Boost Social Security More for Women than Men? Matthew S. Rutledge and John E. Lindner, November 2016

Cognitive Impairment and Social Security's Representative Payee Program Anek Belbase and Geoffrey T. Sanzenbacher, November 2016

An Overview of the Pension/OPEB Landscape

Alicia H. Munnell and Jean-Pierre Aubry, October 2016

What Are the Effects of Doubling Up on Retirement Income and Assets?

Deirdre Pfeiffer, Katrin B. Anacker, and Brooks Louton, September 2016

How Does Student Debt Affect Early-Career Retirement Saving?

Matthew S. Rutledge, Geoffrey T. Sanzenbacher, and Francis M. Vitagliano, September 2016

The Labor Supply of Disabled Veterans: 1995-2014

Matthew S. Rutledge, Geoffrey T. Sanzenbacher, and Caroline V. Crawford, August 2016

The Mortality Effects of Retirement: Evidence from Social Security Eligibility at Age 62 Maria D. Fitzpatrick and Timothy J. Moore, August 2016

How Would Investing in Equities Have Affected the Social Security Trust Fund?

Gary Burtless, Anqi Chen, Wenliang Hou, Alicia H. Munnell, and Anthony Webb, July 2016

Are Early Claimers Making a Mistake?

Alicia H. Munnell, Geoffrey T. Sanzenbacher, Anthony Webb, and Christopher M. Gillis, July 2016

Marital Histories, Gender, and Financial Security in Late Mid-Life: Evidence from Four Cohorts in the Health and Retirement Study

Amelia Karraker and Cassandra Dorius, July 2016

Pension Participation, Wealth, and Income: 1992-2010

Alicia H. Munnell, Wenliang Hou, Anthony Webb, and Yinji Li, July 2016

Elderly Poverty in the United States in the 21st Century: Exploring the Role of Assets in the Supplemental Poverty Measure

Christopher Wimer and Lucas Manfield, November 2015

All working papers are available on the Center for Retirement Research website (http://crr.bc.edu) and can be requested by e-mail (crr@bc.edu) or phone (617-552-1762). 